\title{
The first Neogene record of Zygolophodon (Mammalia, Proboscidea) in Thailand: implications for the mammutid evolution and dispersal in Southeast Asia
}

\author{
Jaroon Duangkrayom, ${ }^{1,2,3}$ Shi-Qi Wang, ${ }^{1}$ Tao Deng, ${ }^{1}$ and Pratueng Jintasakul ${ }^{3}$ \\ ${ }^{1}$ Key Laboratory of Vertebrate Evolution and Human Origins of Chinese Academy of Sciences, Institute of Vertebrate Paleontology \\ and Paleoanthropology, Chinese Academy of Sciences, Beijing, China 〈jakrub2008@hotmail.com〉, 〈jduangkrayom@gmail.com〉, \\ 〈wangshiqi@ivpp.ac.cn〉, 〈dengtao@ivpp.ac.cn〉 \\ ${ }^{2}$ University of Chinese Academy of Sciences, Beijing, China \\ ${ }^{3}$ Northeastern Research Institutes of Petrified Wood and Mineral Resources, Nakhon Ratchasima Rajabhat University, Nakhon Ratchasima, \\ Thailand 〈petrifiedwood_museum@hotmail.com〉
}

\begin{abstract}
Lower and upper third molars of a proboscidean from the Tha Chang sand pits, Nakhon Ratchasima, northeastern Thailand, show a zygodont pattern. The crescentoids are less well developed than those of the type specimen of Zygolophodon gobiensis but similar to those of late Miocene specimens from south China assigned to Z. lufengensis and Z. chinjiensis. On the other hand, the loph(id)s are less oblique and the zygodont crests are less well developed than in Z. lufengensis and Z. chinjiensis. However, it is difficult to erect a new species for these specimens because their anterior loph(id)s are so deeply worn that the morphology of the conelets on these loph(id)s is unclear. Thus, we identify the specimens as Zygolophodon sp. Zygolophodon is known from lower and middle Miocene sediments in Africa while they are usually dated to the early-late Miocene in Europe, South Asia such as Pakistan, and Central and North China. Based on its apparent grade of dental evolution, the new material of Zygolophodon from Thailand is probably late Miocene in age. In addition, this discovery is the first record of a zygodont proboscidean in Southeast Asia.
\end{abstract}

\section{Introduction}

Zygodont proboscideans (Tobien, 1975) have been referred to the family Mammutidae Hay, 1922. Shoshani and Tassy (2005) have reported this family containing two subfamilies, namely Eozygodontinae Mckenna and Bell, 1997 (including only Eozygodon Tassy and Pickford, 1983, from the lower Miocene bed of Africa) and Mammutinae Hay, 1922 (including Zygolophodon Vacek, 1877 from the middle-upper Miocene and its descendant Mammut Blumenbach, 1799 from the Plio-Pleistocene). However, the fossils of palaeomastodont-like proboscideans that first expressed mammutid characters (Sanders et al., 2004) were discovered from the late Oligocene at Chilga, Ethiopia as well as Rasmussen and Gutierrez (2009) also reported a new taxon of Mammutidae from the upper Oligocene bed at the Losodok (Lothidok), Kenya and named it Losodokodon losodokius. In this case, the Losodok mammutid is more primitive and older than Eozygodon so that the subdivision of Eozygodontinae and Mammutinae need to be revised or expanded. In addition, the late Oligocene palaeomastodont-like fossils from Chilga, which suggest the first expression of mammutid features, and possibly that Palaeomastodontidae is not monophyletic but instead is composed of ancestral gomphotheriids (Phiomia) and ancestral mammutids (Palaeomastodon) (Sanders et al., 2004). Hence, the first mammutids occur in the late Oligocene of Africa and then they immigrated into Europe by the end of the early Miocene, and by the middle Miocene had spread throughout Eurasia and into the New World (Tassy, 1986; Mazo, 1996; Sanders, 1996; Tobien, 1996; Sanders et al., 2010).

Zygodont proboscidean fossils have flourished at middle to rather high northern latitudes, in the early Miocene to Pleistocene bed of North America, Europe, northern Africa, and Asia (China and Pakistan). However, there are some reported in low latitude regions such as in the late Oligocene to middle Miocene bed of Kenya, Uganda and Namibia (Pickford, 2007) that are important for the origin of mammutids. In particular, zygodonts have never been reported from Southeast Asia, although zygodont material referred to Zygolophodon is known from Lufeng and Kaiyuan in Yunnan Province, southern China (Chow et al., 1978; Zhang, 1982).

Although zygodonts have not been reported from Thailand, 10 proboscidean genera ranging in age from the middle Miocene to Holocene have been discovered in that country over the past several years. They include Archaeobelodon sp., Prodeinotherium pentapotamiae, Gomphotherium sp., cf. Protanancus macinnesi, Tetralophodon cf. xiaolongtanensis, Tetralophodon sp., Stegolophodon nasaiensis, Sl. cf. latidens, Sl. praelatidens, Sl. cf. stegodontoides, Stegodon elephantoides, S. insignis, S. cf. insignis, S. cf. orientalis, Anancus sp., 
Sinomastodon aff. yangziensis, and Elephas (von Koenigwald, 1959; Buffetaut et al., 1988; Tassy, 1990; Tassy et al., 1992; Saegusa et al., 1999; Nakaya et al., 2002, 2003; Chaimanee et al., 2004; Kunimatsu et al., 2004; Pickford et al., 2004; Suganuma et al., 2006; Thasod, 2007; Duangkrayom et al., 2010; Thasod et al., 2012).

In 2011, new materials representing a zygodont proboscidean were discovered by workers at the sand pit no.10 of Tha Chang sand pits (belonging to Takut Khon Village), Nakhon Ratchasima Province, northeastern part (Fig. 1). The Tha Chang sand pits were given the numbers 1 through 10 by the Thailand-Japan team, with the Takut Khon Village sand pit being number 10. A lower molar was collected by the Northeastern Research Institute of Petrified Wood and Mineral Resources, Nakhon Ratchasima Rajabhat University, and an upper molar was collected by the Sukhothai Airport Natural History Museum. Although the two teeth did not come from the same individual skeleton, their morphology suggests that they belong to the same zygodont proboscidean species. The specimens described in this paper are the first record of any zygodont proboscidean for Thailand, and indeed for Southeast Asia. They have important implications for understanding zygodont evolution and dispersal patterns.

\section{Materials and methods}

Materials for study include the right lower third molar (m3), NRRU-TKK-001 and the left upper third molar (M3), PRY-200 from Tha Chang sand pits (Figs. 2-4). The materials for comparison include AMNH19414, AMNH8137, AMNH26461, AMNH26476, DPC9009, DPC12598, DPC5920, F:AM23339, GIU, IVPP-V2485, IVPP-V5584, IVPP-V5585, IVPP-V4688.1, IVPP-RV77001, IVPP-unnumbered, KNM-LS18244, KNMME17, KNM-ME7545, KNM-ME7547, no. 2280/2, PIN2202-4, PIN2202-5, PIN2202-6, RAM908, THP-00079, THP-10022,

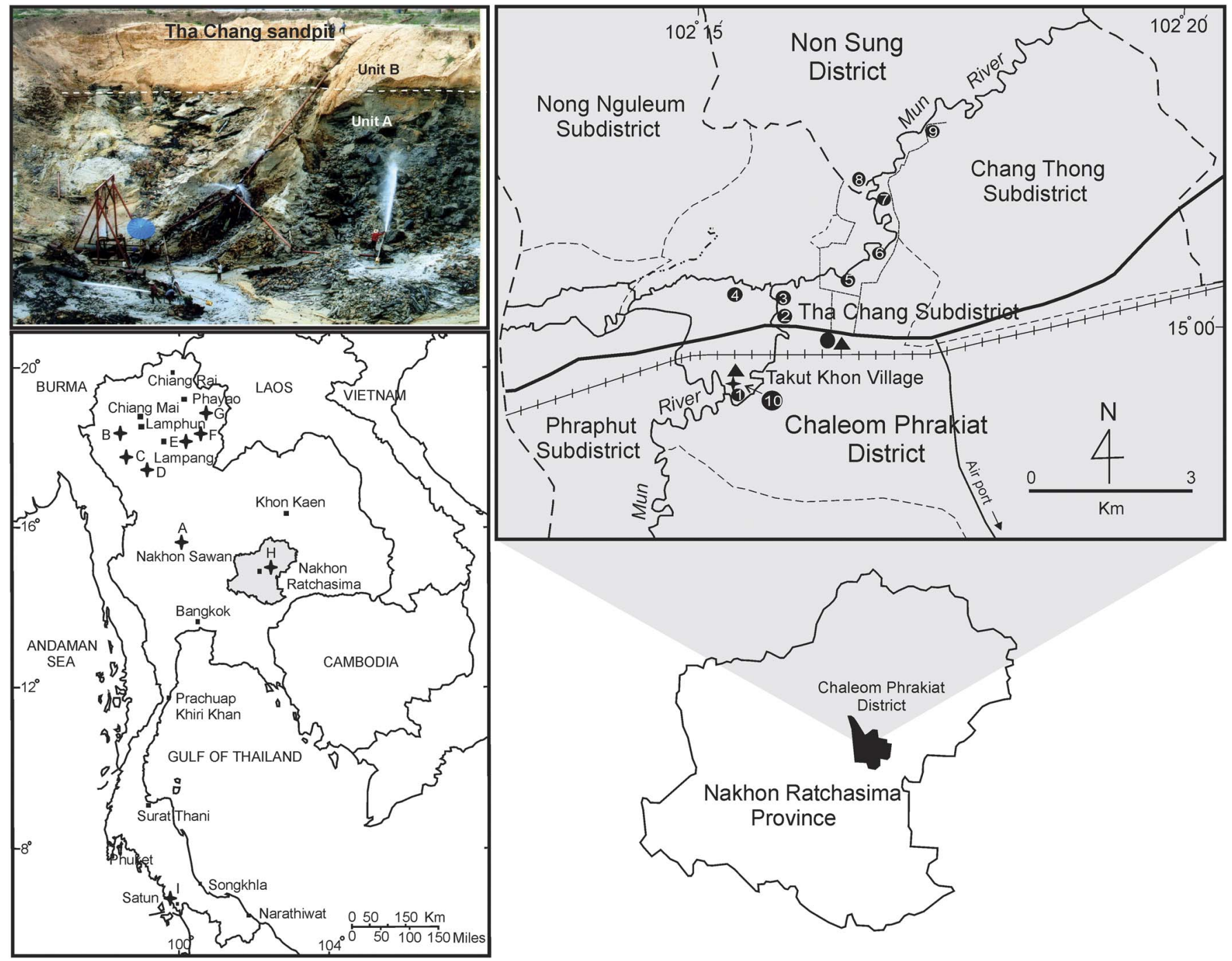

Figure 1. Map of Thailand showing fossil proboscidean localities. Lower left: A, Dechatiwongse Bridge, Nakonsawan Province; B, Mae Soi locality in Chom Thong District, Chiang Mai Province; C, Ban Na Sai coal mine, Lumphun Province; D, Mae Teep coal mine, Lumphun Province; E, Mae Moh coal mine, Lumpang Province; F, Sop Mae Tham locality, Lumpang Province; G, Chiang Muan coal mine, Proyao Province; H, Tha Chang sand pit, Nakhon Ratchasima Province (shaded); I, Wang Kuai cave, Thungwa District, Satun Province. Top left: Photo of the Tha Chang sand pit is marked to indicate the extent of the lower reduced unit (Unit A) and upper oxidized unit (Unit B). Top right: Map of Chaleom Phrakiat District shows the Tha Chang sand pits. The Takut Khon Village sand pit is in number 10. 


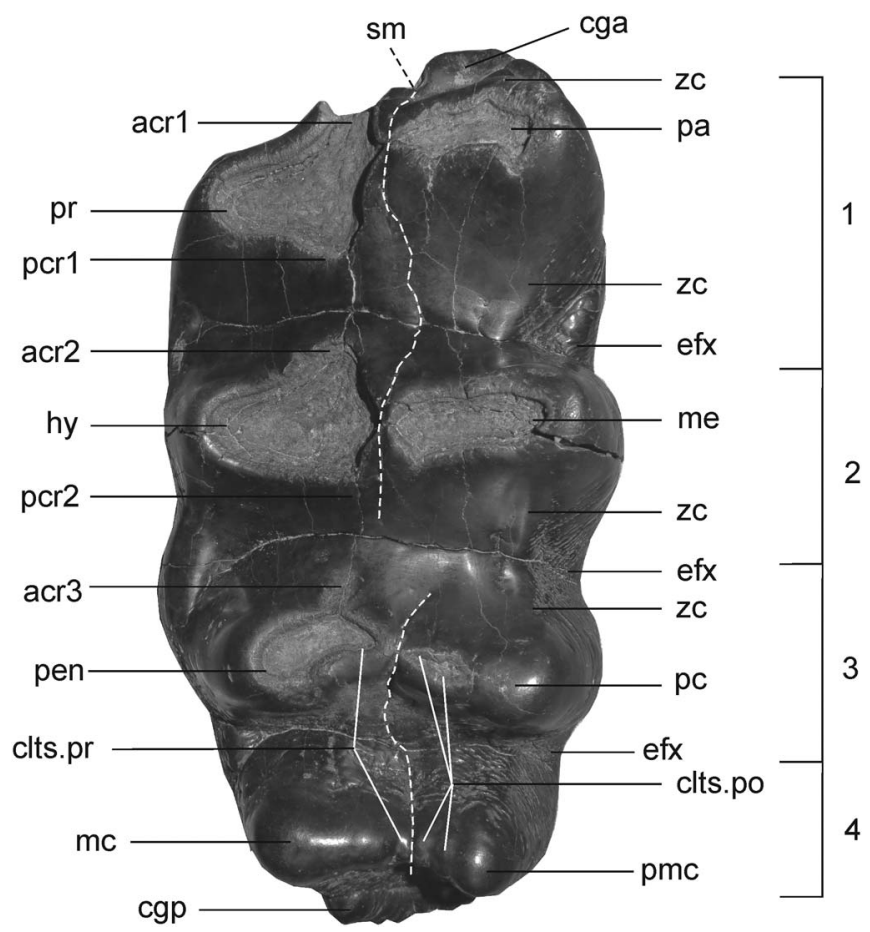

Figure 2. Dental nomenclature: (acr1, 2, 3), anterior pretrite crescentoids of the first, second and third loph(id)s; (cga), anterior cingulum; (cgp), posterior cingulum (talon(id)); (clts.pr), pretrite conelets; (clts.po), posttrite conelets; (efx), ectoflexus; (hy), hypocone (pretrite main cone of the second loph(id)); (mc), main cone (pretrite main cone of the fourth loph(id)); (me), metacone (posttrite main cone of the second loph(id)); (pa), paracone (posttrite main cone of the first loph(id)): (pc), third posttrite cusp (posttrite main cone of the third loph(id)); (pcr1, 2), posterior pretrite crescentoids of the first and second loph(id)s; (pen), postentoconule (pretrite main cone of the third loph(id)): (pmc), posttrite main cone of the fourth loph(id); (pr), protocone (pretrite main cone of the first loph(id)); (sm), median sulcus; (zc), zygodont crest.

THP-10031, THP-18908, THP-18903, YV031, and YV0132 (Table 1).

Repositories and institutional abbreviations.-AMNH, American Museum of Natural History, New York; DPC, Duke Primate Center, North Carolina; F:AM, Frick Collection, American Museum of Natural History, New York; IVPP-V, Institute of Vertebrate Paleontology and Paleoanthropology, vertebrate collection, Beijing; NRRU-TKK, Northeastern Research Institute of Petrified Wood and Mineral Resources, Nakhon Ratchasima Rajabhat University, Takut Khon Village collection, Nakhon Ratchasima; PIN, Paleontological Institute, Moscow; PRY, Sukhothai Airport Natural History Museum, Sukhothai, Mr. Piriya Vachajitpan collection; RAM, Raymond M. Alf Museum of Paleontology, Claremont, California; THP, Natural History Museum, Tianjin (Museum of Huangho and Paiho).

\section{Systematic paleontology}

Dental nomenclature follows Tassy (1996). Description of occlusal features of zygodont cheek tooth M3 follows Tobien (1975) (Fig. 2) and measurements are in millimeters.

Order Proboscidea Illiger, 1811

Family Mammutidae Hay, 1922

Genus Zygolophodon Vacek, 1877
Type species.-Mastodon turicensis Schinz, 1824 (for more details including the non-validity of "Mastodon tapiroides Desmarets, 1822", sometimes used by earlier authors, see Tassy, 1985).

Diagnosis. - A mammutid with intermediate and third molars in which the pretrite and posttrite elements are of bunodont character and arranged in clearly yoke-like transverse crests. D4 and all molars are zygodont, having a transverse or slightly oblique loph. In lateral view, the main cusps are wide at the base but taper to an apical point. Transverse valleys have few and small accessory cusps. Worn loph(id)s become sharpened at their summits and show a more zygodont character; zygodont crests show a sharp angle between the lingual and posterior surfaces of the principal lingual cuspids in the lower molars, and between the corresponding surfaces of the buccal cusps in the upper molars; the accessory conules are not developed but rather have crescentoids descending into the transverse valley between loph(id)s on the pretrite side at both upper and lower molars; lophs of upper molars are normal to the long axis of the crown; lophids of lower molars are more or less oblique (i.e., postero-external to antero-internal); upper third molar bears three lophs plus a strong talon or four lophs plus a weak cingulum; and lower third molar bears four lophids plus a more or less strong cingulid (Tobien in Shoshani and Tassy, 1996; Mazo and van de Made, 2012).

\section{Zygolophodon sp.}

Figures 3 and 4

Occurrence.-Both specimens were found in sand pit no.10 of Tha Chang sand pits (14 $\left.59^{\prime} 50.27^{\prime \prime N}, 102^{\circ} 14^{\prime} 47.50 " \mathrm{E}\right)$ belonging to Takut Khon Village, Tha Chang Subdistrict, Chaloem Prakiat District, Nakhon Ratchasima Province (Fig. 1). Howard et al. (2003) and Haines et al. (2004) subdivided the sediments in the sand pits along the Mun River into a lower reduced unit (Unit A) and an upper oxidized unit (Unit B) (Fig. 1). The lower reduced unit is composed of reduced gray sediment in the form of cross-bedded, stratified to massive sand and gravel, with mud lenses. Abundant Neogene faunal and floral fossils were discovered in this unit (Suteethorn et al., 1997; Sato, 2002; Nakaya et al., 2002; Howard et al., 2003). The materials described in this study were found in the lower reducing unit. However, they were discovered by sand pit workers, and their detailed lithological context is unclear because the water jets used during the sand excavation process caused extensive damage to the strata and fossils collapsed.

Description.-m3, NRRU-TKK001 (Fig. 3). This right lower third molar is missing the first lophid. There are $(\times 1) 3 \times$ lophids plus a weak talonid (posterior cingulid). A crescentoid is present and the two half lophids are arranged as yoke-like transverse crests. The second lophid is oblique to the long axis of the crown, and the third lophid is slightly oblique. The lophids become more anteroposteriorly constricted at their apices. The first lophid is broken out. The second lophid is severely worn. The third lophid is also worn, bearing a narrow, transversely elongated wear facet. 

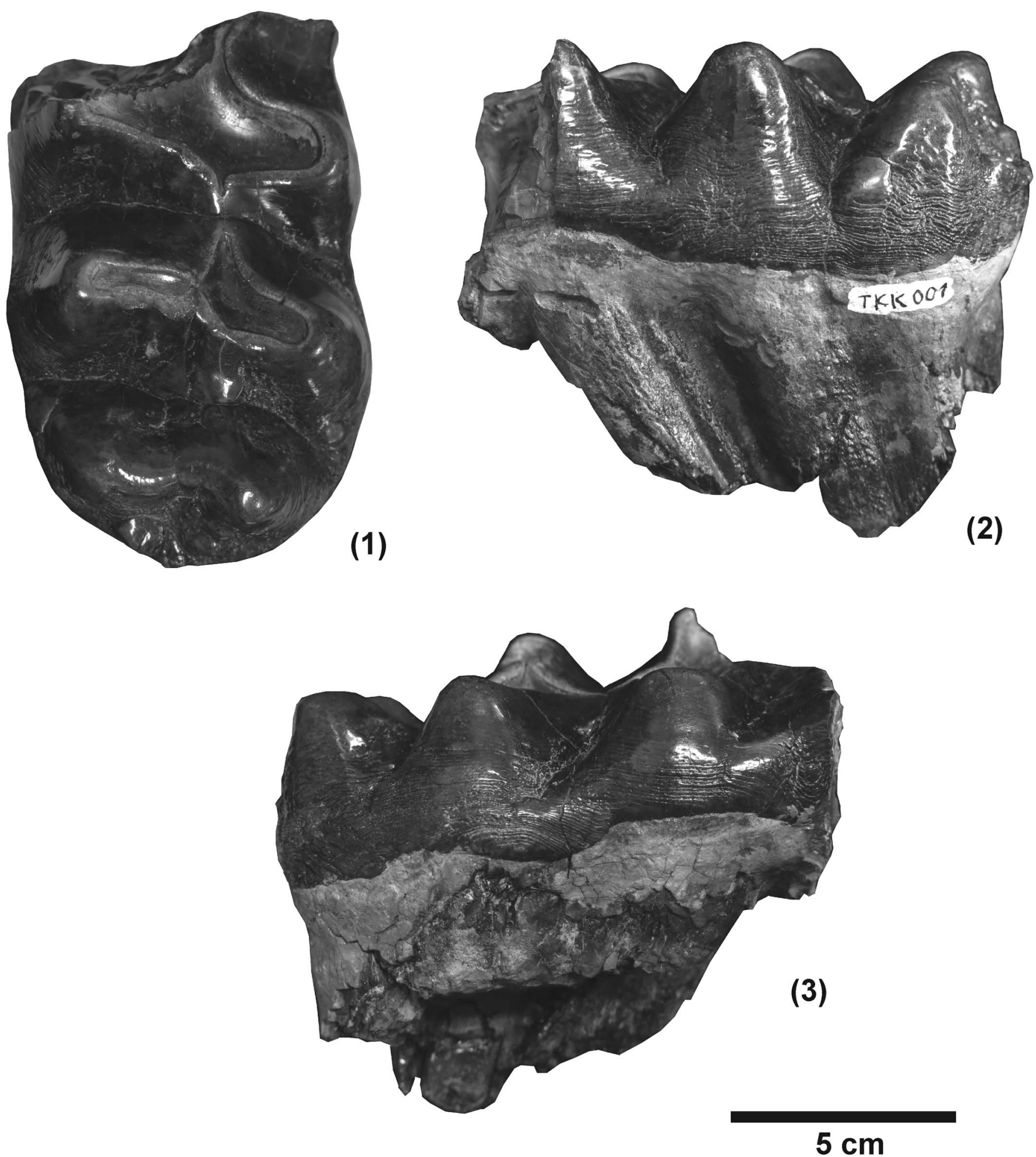

Figure 3. The lower third molar of Zygolophodon sp. from Tha Chang sand pit no. 10, NRRU-TKK001: (1) occlusal view, (2) lingual view, (3) buccal view.

There are anterior and posterior crescentoids (acr and pcr) on the pretrite side that show narrow and elongated wear surfaces. The third posttrite half lophid has a main cone and smaller adaxial conelets (clts.po), but conelets are not clearly evident on the pretrite half lophid. The unworn fourth lophid has a main cone and smaller adaxial conelet on the pretrite half lophid while the posttrite has a large and transversely elongate main cone, however the conelet is furrow-like. Zygodont crests (zc) are present, but not so strong. The cingulids are distinctly reduced. A median sulcus divides the lophids. The talonid (posterior cingulid) is shelf-like and thicker on the pretrite side than on the posttrite side. No cementum is present (Fig. 3). 

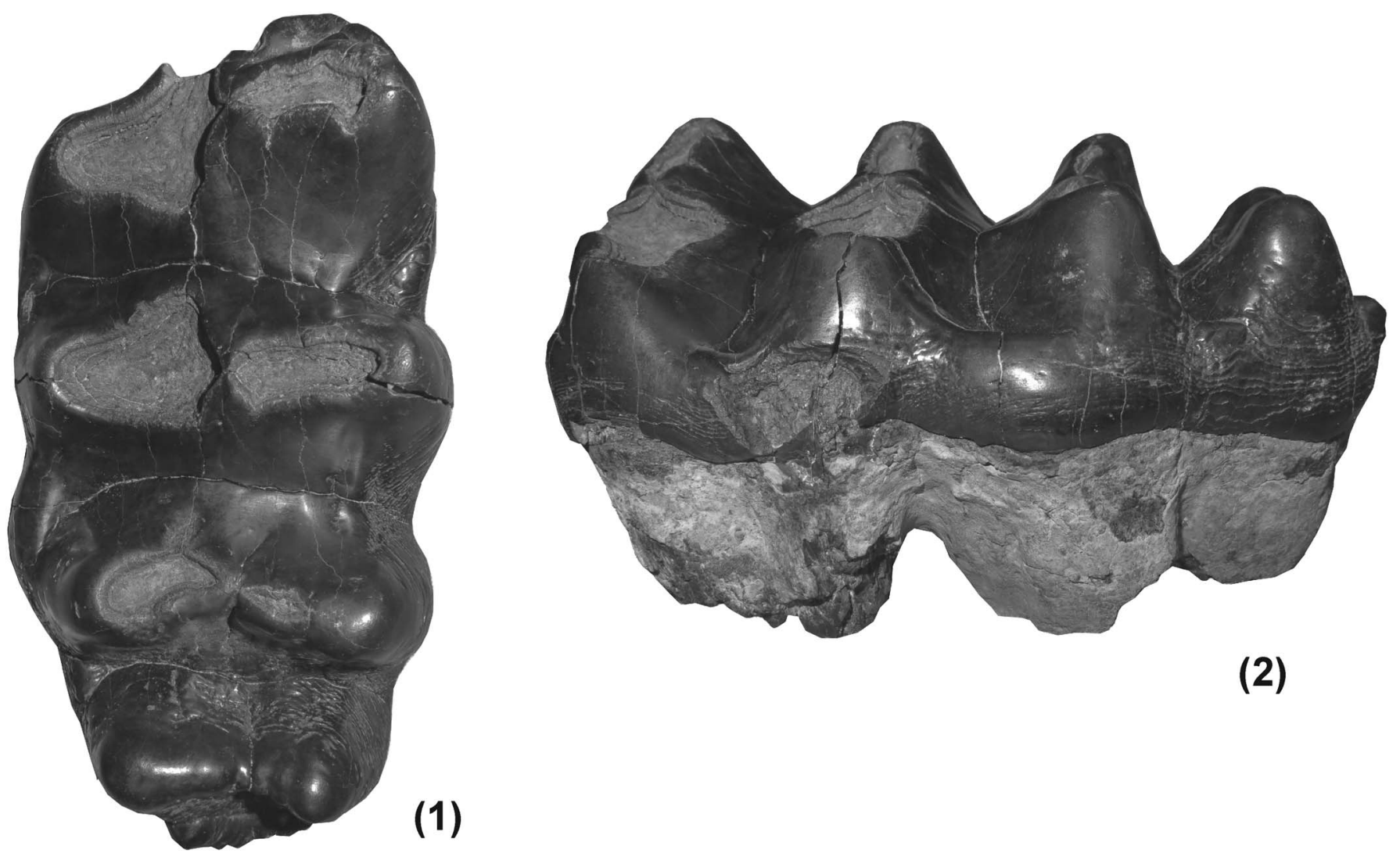

(2)

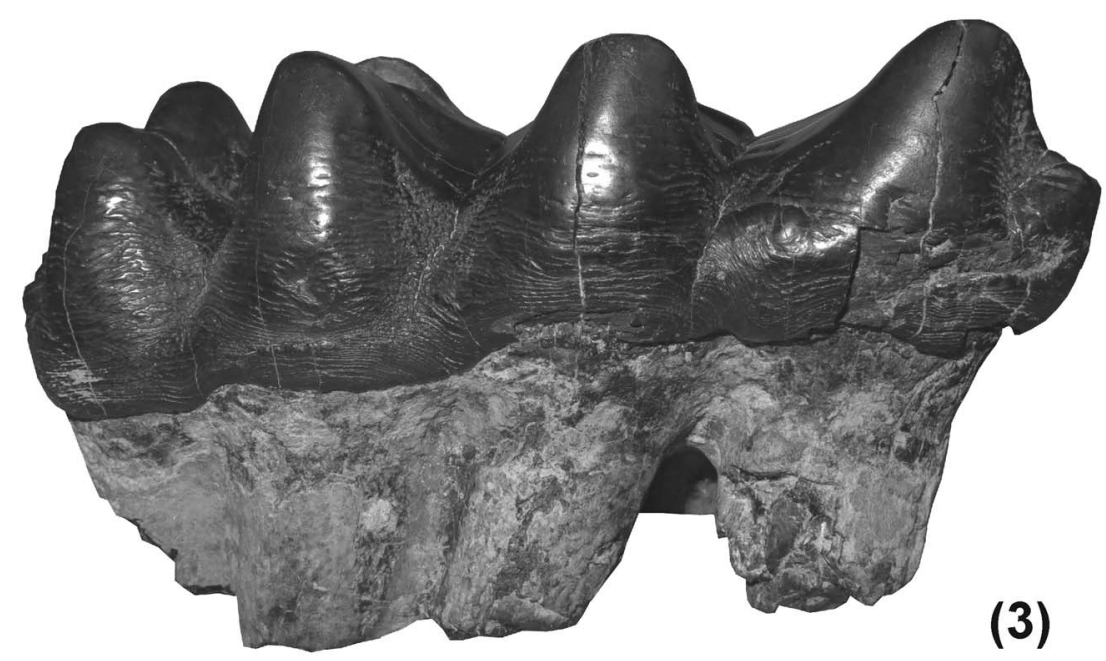

\section{$5 \mathrm{~cm}$}

Figure 4. The upper third molar of Zygolophodon sp. from Tha Chang sand pit no. 10, PRY200: (1) occlusal view, (2) lingual view, (3) buccal view.

M3, PRY200. This upper left molar has four lophs, in addition to anterior and posterior cingula. The lingual cingulum is quite strong, and the buccal cingulum is only evident in the vicinity of the first valley. The crowns of the first and second lophs are deeply worn, and the third loph is also somewhat worn. The crescentoids are present in the pretrite side and arranged in straight lines that run perpendicular to the anteroposterior axis of the crown, and appear to be yoke-like in this molar. The first and second lophs bear clear zygodont crests. The pretrite and posttrite half lophs are separated by a strong median sulcus. The molar is wider anteriorly than posteriorly. In lateral view, the posterior pretrite crescentoid of the first loph (pcr1) is well-developed and extends downward to the base of the adjacent valley, where it joins the anterior pretrite 


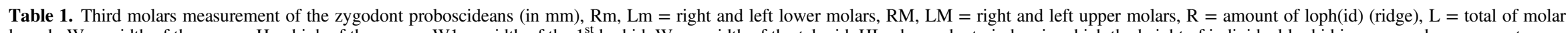
leangh, $\mathrm{W}=$ width of the crown, $\mathrm{H}=$ high of the crown, $\mathrm{W} 1$ = width of the $1^{\text {st }}$ lophid, $\mathrm{Wx}=$ width of the talonid, $\mathrm{HI}=$ hypsodonty index, in which the height of individual lophid is expressed as a percentage

\begin{tabular}{|c|c|c|c|c|c|c|c|c|c|c|c|c|c|c|c|}
\hline No. & Taxon & Specimen & Measurement Referred & $\mathrm{R}$ & $\mathrm{L}$ & $\mathrm{W}$ & $\mathrm{H}$ & $\mathrm{W} 1$ & $\mathrm{~W} 2$ & W3 & $\mathrm{W} 4$ & Wx & $\mathrm{HI}$ & WI & ET \\
\hline NRRU-TKK-001 & Zygolophodon sp. & $\mathrm{Rm} 3$ & owner & $(\mathrm{x} 1) 3 \mathrm{x}$ & $>140^{*}$ & 76.5 & $42.8+$ & 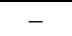 & 75.2 & 76.5 & 69.6 & 28.1 & $56+$ & $54.64+$ & $3.2-5.1$ \\
\hline PRY-200 & Z. sp. & LM3 & owner & $\mathrm{x} 4 \mathrm{x}$ & 152.2 & 80.8 & $41.5+$ & 78.7 & 80.8 & 79.3 & 60.4 & 30 & $51.36+$ & 53.09 & 3.8 \\
\hline KNM-LS18244 & Losodokodon losodokius & RM3 & Rasmussen\&Gutierrez, 2009 & $3 \mathrm{x}$ & 92.26 & 53.66 & $30.7+$ & 51.6 & 53.6 & $42.1+$ & - & - & $51.23+$ & 58.16 & - \\
\hline KNM-ME17 & Eozygodon morotoensis & LM3 & Tassy\&Pickford, 1983 & $3 \mathrm{x}$ & 110.4 & 74.4 & 40.8 & 71.7 & 74.4 & 64.7 & - & - & 54.84 & 67.39 & - \\
\hline KNM-ME7545 & E.morotoensis & RM3 & Tassy\&Pickford, 1983 & $3 \mathrm{x}$ & 109.3 & 71.3 & 40 & 67.4 & 71.3 & 62.6 & - & - & 56.1 & 65.23 & - \\
\hline KNM-ME7547 & E.morotoensis & $\mathrm{Rm} 3$ & Tassy\&Pickford, 1983 & $\mathrm{x} 3 \mathrm{x}$ & 123.9 & 67.4 & & 61.6 & 67.4 & 64.4 & - & - & - & 54.4 & - \\
\hline DPC 9009 & Z. aegyptensis (type) & $\mathrm{Rm} 3$ & Sanders\&Miller, 2002 & $\mathrm{x} 4 \mathrm{x}$ & 148.8 & 55.8 & - & - & - & - & - & - & - & 37.5 & - \\
\hline DPC12598 & Z. aegyptensis & RM3 & Sanders\&Miller, 2002 & $x 4 x$ & 121.1 & 64.7 & 43 & - & - & - & - & - & 66.46 & 53.43 & - \\
\hline \multirow{5}{*}{ DPC5920 } & Z. aegyptensis & RM3 & Sanders\&Miller, 2002 & $? 4 ?$ & 116 & 75.6 & 49 & - & - & - & - & - & 64.81 & 65.17 & $5.8-6.8$ \\
\hline & Z. turicensis & $\mathrm{Rm} 3$ & Tassy, 1977 & $x 4 x$ & 157.5 & 85.5 & - & 78.5 & 85.5 & 85 & 53 & - & - & 54.29 & - \\
\hline & Z. turicensis & Lm3 & Tassy, 1977 & $\mathrm{x} 4 \mathrm{x}$ & 148 & 79.5 & - & 73.5 & 79.5 & 79 & 54 & - & - & 53.72 & - \\
\hline & Z. turicensis & RM3 & Tassy, 1977 & $x 4 x$ & 140 & 84 & - & - & 84 & 82 & 68 & - & - & 60 & - \\
\hline & Z. turicensis & LM3 & Tassy, 1977 & $\mathrm{x} 3 \mathrm{x}$ & 149.5 & 84 & - & 84 & 82.5 & 82 & - & 58 & - & 56.19 & \\
\hline $2280 / 2$ & Z. atavus (type) & $\mathrm{Rm} 3$ & Borissiak, 1936 & $\mathrm{x} 4 \mathrm{x}$ & 163 & 90 & - & - & - & - & - & - & - & 55.21 & - \\
\hline $2280 / 2$ & Z. atavus & Lm3 & Borissiak, 1936 & $\mathrm{x} 4 \mathrm{x}$ & 172 & 95 & - & - & - & - & - & - & - & 55.23 & - \\
\hline AMNH8137 & Z. proavus (type) & RM3 & Lofgren\&Anand, 2011 & 4 & 150.2 & 95.8 & - & 87.6 & 95.8 & 85.3 & 60.6 & - & - & 63.78 & - \\
\hline RAM908 & Z. cf. proavus & LM3 & Lofgren\&Anand, 2011 & 4 or $x 3 x$ & 127.3 & 74.4 & - & 73.8 & 74.4 & 66.1 & 45.8 & - & - & 58.44 & - \\
\hline RAM908 & Z. cf. proavus & RM3 & Lofgren\&Anand, 2011 & 4 or $x 3 x$ & 128.2 & 76 & - & 76 & 75.8 & 67.4 & 48.3 & - & - & 59.28 & - \\
\hline F:AM23337 & Z. cf. proavus & LM3 & Lofgren\&Anand, 2011 & 4 & 153.5 & 89.1 & - & 89.1 & 84.7 & 73.3 & 56.7 & - & - & 58.05 & - \\
\hline F:AM23337 & Z. cf. proavus & RM3 & Lofgren\&Anand, 2011 & 4 & 150.2 & 92.3 & - & 92.3 & 88.8 & 78.8 & 61 & - & - & 61.45 & - \\
\hline PIN2202-4 & Zygolophodon gromovae & M3 & Tobien et al., 1988 & 4 & 182 & 105 & & & & & & & & 57.69 & \\
\hline PIN2202-5 & Z. gromovae & M3 & Tobien et al., 1988 & 4 & 182 & 107 & & & & & & & & 58.79 & \\
\hline PIN2202-6 & Z. gromovae & RM3 & Tobien et al., 1988 & 4 & 164 & 95 & & & & & & & & 57.93 & \\
\hline AMNH-26461 & Z. gobiensis (type) & $\mathrm{Rm} 3$ & owner & $\mathrm{x} 4 \mathrm{x}$ & 195 & 87 & 72 & 90 & - & - & - & - & 82.76 & 44.62 & - \\
\hline AMNH-26476 & Z. gobiensis & $\mathrm{Rm} 3$ & Tobien et al., 1988 & $4 \mathrm{x}$ & 160 & 79 & - & - & - & - & - & - & - & 49.38 & - \\
\hline IVPP-V5584 & $\begin{array}{l}\text { Z. gobiensis } \\
\text { (Miomastodon tongxinensis) }\end{array}$ & $\mathrm{Rm} 3$ & owner & $x 4 x$ & 151.4 & 74.7 & $47.5+$ & 67.8 & 74.7 & 69.7 & 51 & 21 & $63.6+$ & 49.34 & $5-7.6$ \\
\hline IVPP-V5585 & $\begin{array}{l}\text { Z. gobiensis } \\
\text { (Miomastodon tongxiensis) }\end{array}$ & RM3 & owner & $\mathrm{x} 4$ & 133.5 & 82.1 & $50+$ & 81.6 & 82.1 & 65.2 & 41.8 & - & $60.9+$ & 61.50 & $5-7.6$ \\
\hline IVPP-V4688.1 & $\begin{array}{l}\text { Z. gobiensis } \\
\text { (Z. chinjiensis) }\end{array}$ & RM3 & owner & $x 4 x$ & 177.2 & 93 & 63.6 & 90.8 & 93 & 83 & 70 & 37 & 68.4 & 52.48 & - \\
\hline IVPP-V2487 & $\begin{array}{l}\text { Z. gobiensis } \\
\text { (Z. (Turicius) nemongnensis) }\end{array}$ & RM3 & owner & $x 4 x$ & 191.8 & 91 & 63.4 & 87 & $91+$ & 84.7 & 75 & 51.6 & 69.67 & 47.45 & - \\
\hline YV0131 & $\begin{array}{l}\text { Z. gobiensis } \\
\text { (Z. lufengensis) }\end{array}$ & Lm3 & Zhang, 1982 & $\mathrm{x} 4 \mathrm{x}$ & 151 & 74.8 & 53 & 65 & 74.8 & 73.2 & 65.5 & & 70.86 & 49.54 & - \\
\hline YV0132 & $\begin{array}{l}\text { Z. gobiensis } \\
\text { (Z. lufengensis) }\end{array}$ & LM3 & Zhang, 1982 & $\mathrm{x} 4 \mathrm{x}$ & 179 & 93.9 & 70.3 & - & - & - & - & - & 74.87 & 52.46 & - \\
\hline IVPP-no number & $\begin{array}{l}\text { Z. gobiensis } \\
\text { (Z. jiningensis) }\end{array}$ & RM3 & Chow\&Chang, 1974 & $\mathrm{x} 4 \mathrm{x}$ & 135 & 81.5 & 41 & - & - & - & - & - & 50.31 & 60.37 & - \\
\hline AMNH 19447 & Z. chinjiensis (type) & RM3 & Osborn, 1929 & $4 \mathrm{x}$ & 160 & 91 & 52 & - & - & - & - & - & 57.14 & 56.88 & - \\
\hline AMNH 19414 & $\begin{array}{l}\text { Z. metachinjiensis } \\
\text { (type) }\end{array}$ & $\mathrm{Rm} 3$ & Osborn, 1929 & $4 \mathrm{x}$ & 214 & 85 & 75 & - & - & - & - & - & 88.24 & 39.72 & - \\
\hline GIU & Z. metachinjiensis & LM3 & Tassy, 1983 & $\mathrm{x} 4$ & 191.3 & 96 & 79 & 92.4 & 96 & 94.6 & 75 & - & 82.29 & 50.18 & - \\
\hline IVPP-V2485 & $\begin{array}{l}\text { Mammut borsoni } \\
\text { (Z. shansiensis) }\end{array}$ & $\mathrm{Rm} 3$ & owner & $\mathrm{x} 5$ & 190 & 88.5 & 56 & 87 & 88.5 & 86 & 79 & 51.5 & 63.28 & 46.58 & - \\
\hline IVPP-RV77001 & $\begin{array}{l}\text { Mammut borsoni } \\
\quad \text { (?Pliomastodon cf. matthewi) }\end{array}$ & $\mathrm{Rm} 3$ & owner & $(\mathrm{x} 1) 3 \mathrm{x}$ & $168^{*}$ & 88.7 & $58+$ & - & 88.7 & 85 & 67.2 & 36 & $65.39+$ & $52.80+$ & $5-6.5$ \\
\hline THP-00079 & M. borsoni & LM3 & Tobien et al., 1988 & $\mathrm{x} 4 \mathrm{x}$ & 193 & 117 & 54 & - & - & - & - & - & 46.15 & 60.62 & - \\
\hline THP-00079 & M. borsoni & RM3 & Tobien et al., 1988 & $\mathrm{x} 4 \mathrm{x}$ & 197 & 119 & 56.8 & - & - & - & - & - & 47.73 & 60.41 & - \\
\hline THP-10022 & M. borsoni & LM3 & Tobien et al., 1988 & $\mathrm{x} 4 \mathrm{x}$ & 170 & 94 & 53 & - & - & - & - & & 56.38 & 55.29 & - \\
\hline THP-10031 & M. borsoni & LM3 & Tobien et al., 1988 & $x 4 x$ & 159 & 92 & 61 & - & - & - & - & - & 66.30 & 57.86 & - \\
\hline THP-18908 & M. borsoni & LM3 & Tobien et al., 1988 & $\mathrm{x} 4 \mathrm{x}$ & 172 & 100 & 64 & - & - & - & - & & 64.00 & 58.14 & - \\
\hline THP-18903 & M. borsoni & RM3 & Tobien et al., 1988 & $\mathrm{x} 4 \mathrm{x}$ & 174 & 103 & 55 & - & - & - & - & - & 53.40 & 59.20 & - \\
\hline
\end{tabular}

*Estimate measured. 
crecentiod of the second loph (acr2). A similar feature is also present in the valley between the second and the third lophs. However, the valley between the third and fourth lophs is open. No cementum remains in the valleys.

The pretrite of the first loph is displaced slightly posteriorly relative to the posttrite part. The zygodont crest of the first loph is stronger than those of the other lophs, and continuous with the anterior cingulum. Anterior and posterior pretrite crescentoids (acr1 and pcr1) are present. However, their surfaces are deeply worn. The acrl is connected to the anterior cingulum.

The second loph is aligned with the transverse axis of the crown, and is deeply worn. An anterior pretrite crescentoid (acr2) is present, and extends downward to the base of the adjacent valley, whereas the posterior pretrite crecentoid (pcr2) is not prominent. The pretrite of the third loph is slightly posteriorly, while the posttrite is straight. The wear surface of the third loph is moderately worn. The posttrite half loph has a rather large main cone and small adaxial conelets (clts.po), which appear furrow-like. However, the morphology of the conelets is not clear in the pretrite half loph because of surface wear. The anterior pretrite crescentoid (acr3) is slightly worn and narrow in shape. The posterior pretrite crescentoid (pcr3) is very weak in this loph. The unworn fourth loph shows two small adaxial conelets (clts.po) on the posttrite side, which appear furrow-like. The main cone is quite large. The pretrite half loph has a large and transversely elongate main cone, and a small conelet near the median sulcus. The anterior crescentoid (acr4) is clearly and extends down to the base of the nearby valley. The talon (posterior cingulum) is shelf-like, and better developed on the pretrite side than on the posttrite side (Fig. 4).

Materials.-The right lower third molar (m3) is stored at the Northeastern Research Institute of Petrified Wood and Mineral Resources, Nakhon Ratchasima Rajabhat University, as NRRU-TKK-001. The left upper third molar (M3) is stored at the Sukhothai Airport Natural History Museum, as PRY-200 (Figs. 2-4).

Remarks.-The lophids of the specimen NRRU-TKK-001 (right $\mathrm{m} 3$ ) are more oblique than the loph of PRY-200 (left M3). This is a generally different pattern between the lower and upper molar, especially in the zygodont proboscideans. The enamel wear surfaces are narrow, transversely elongated and yoke-like (Tobien, 1973b). Both of specimens from Tha Chang have clear zygodont crests. The conelets on the posttrite side (clts.po.) are better developed than those on the pretrite side (clts.pr.). The conelets and half loph(id)s are somewhat less regularly arranged than in the bunodont molars of proboscideans such as Gomphotherium. In addition, the mesoconelets of Gomphotherium are blunter and more morphologically distinct from the zygodont proboscideans (Tobien, 1973b). The pretrite central conules of bunodonts are arranged in a conule-like pattern, rather than a yoke-like pattern as in the specimens from Tha Chang. These characters above indicate that the Tha Chang specimens are the zygodont proboscideans.

Compared with the oldest zygodont proboscidean, Losodokodon losodokius, from the late Oligocene of Losodok (Lothidok), Kenya (Rasmussen and Gutierrez, 2009), and the early to middle Miocene species, Eozygodon morotoensis, from
Moroto, Uganda (Pickford and Tassy, 1980; Tassy and Pickford, 1983; Pickford, 2007) that they have three loph(id)s in the third upper and lower molars. The fourth loph(id)s in m3/ M3 are absent or poor developed. On the contrary, the Tha Chang specimens have four loph(id)s with the posterior cingula and larger in molar size (Tables 1-3; Fig. 5).

The zygodont crests of the Tha Chang specimens are not strongly developed, in contrast to the condition in Mammut. In addition, the lateral cingula of the Tha Chang specimens are less well developed than in Mammut, whereas the crescentoids of the Tha Chang specimen are more distinct than in Mammut. According to the differentiation between the Tha Chang specimens and the oldest and youngest zygodont proboscideans, Losodokodon losodokius, Eozygodon morotoensis, and Mammut, the dental features such as molar size and well-developed anterior and posterior ridges of Tha Chang specimens indicate that it belongs to Zygolophodon.

Comparison between the Tha Chang specimens and the Egyptian early Miocene zygolophodont Zygolophodon aegyptensis (see Sander and Miller, 2002, p. 398, fig. 9) reveals that the third and fourth lophids of $\mathrm{m} 3$ are strongly convex anteriorly in the Egyptian species but quite straight in the Tha Chang specimen. In lateral view, the lophids of Z. aegyptensis are more widely separated than those of the Tha Chang specimens. However, the anterior and posterior pretrite crescentoids of the $\mathrm{m} 3$ of $Z$. aegyptensis are clearly in contact with each other according to wear, which is also the case in the Tha Chang specimen. The complete M3 of Z. aegyptensis possesses three lophs or variably a fourth loph, a thin anterior cingulum composed of numerous tiny tubercles, and a moderate-sized heel; whereas the Tha Chang M3 possesses four lophs and a tiny posterior cingulum. In addition, the lower $\mathrm{m} 3$ from Tha Chang is wider but shorter than that of the Egyptian species, whereas the upper M3 from Tha Chang is both wider and longer than its Egyptian counterpart (Tables 1-3; Fig. 5.1, 5.2).

The M3 of Zygolophodon cf. proavus, RAM 908 (see Lofgren and Anand, 2011, p. 1393, fig. 4) from the middle Miocene of the Mud Hills, Mojave Desert, California, North America resembles the Tha Chang M3 in several respects. In Z. cf. proavus central conules are not present; however, the wear facet on the protocone extends onto thickened enamel that is present on both anterior and posterior slopes. The posterior and anterior extensions of this wear facet give a false impression that the central conules are only weakly developed. These characters are reminiscent of the Tha Chang M3, but in other important respects this tooth differs from its equivalent in $Z$. cf. proavus. The fourth loph is much less well developed in $Z$. cf. proavus than in the Tha Chang M3. In Z. cf. proavus, the first three lophs reduce their transverse dimension anteroposteriorly, unlike in the Tha Chang M3, and an ectoflexus is present on all three interlophs in Z. cf. proavus but only on the first interloph of the Tha Chang M3. Moreover, the labial cingulum is better-developed in Z. cf. proavus than in the Tha Chang M3. However, the upper molars of $Z$. cf. proavus described by Lofgren and Anand (2011) are smaller than other specimens of the $Z$. proavus. The Tha Chang M3 is longer and wider than RAM908, but narrower than other specimens of $Z$. proavus (Tables 1, 3; Fig. 5.2). 
Table 2. The lower third molars (m3) morphology of the Old Word zygodont proboscideans.

\begin{tabular}{|c|c|c|c|c|c|c|c|c|}
\hline \multirow[b]{2}{*}{ Taxa } & \multicolumn{8}{|c|}{ Dental morphology } \\
\hline & $\begin{array}{l}\text { Dental } \\
\text { morphotypes }\end{array}$ & $\begin{array}{l}\text { Pretrite adaxial } \\
\text { conelets }\end{array}$ & $\begin{array}{l}\text { Zygodont } \\
\text { crests }\end{array}$ & Crescentoids & $\begin{array}{l}\text { Obliquity of lophids } \\
\text { (degree) }\end{array}$ & Cingulids & Forth lophid & $\begin{array}{l}\text { Molar sizes and } \\
\text { shapes }\end{array}$ \\
\hline Eozygodon morotoensis & Gracile & Small or absent & Visible & Visible & High & $\begin{array}{l}\text { Well developed } \\
\text { in upper molar }\end{array}$ & Undeveloped & Small \\
\hline Zygolophodon aegyptensis & Robust & Rather strong & Visible & $\begin{array}{l}\text { Strong and rather } \\
\text { blunt }\end{array}$ & $\begin{array}{l}\text { High in two anterior } \\
\text { lophids }\end{array}$ & Well developed & Developed & $\begin{array}{l}\text { Small, long and } \\
\text { narrow }\end{array}$ \\
\hline $\begin{array}{l}\text { Z. turicensis } \\
\text { Z. atavus }\end{array}$ & $\begin{array}{l}\text { Gracile } \\
?\end{array}$ & $\begin{array}{l}\text { Strong } \\
?\end{array}$ & $\begin{array}{l}\text { Strong } \\
?\end{array}$ & $\begin{array}{l}\text { Strong } \\
?\end{array}$ & $\begin{array}{l}\text { Moderate to high } \\
\text { ? }\end{array}$ & $\begin{array}{l}\text { Well developed } \\
?\end{array}$ & $\begin{array}{l}\text { Developed } \\
\text { ? }\end{array}$ & $\begin{array}{l}\text { Medium } \\
\text { Large, wide }\end{array}$ \\
\hline Z. gobiensis & Robust & Small or absent & Visible & $\begin{array}{l}\text { Strong and rather } \\
\text { blunt }\end{array}$ & Low & Reduced & Less Developed & Medium to large \\
\hline $\begin{array}{l}\text { Z. gobiensis (Miomastodon } \\
\text { tongxinensis) }\end{array}$ & Robust & Small & Visible & Visible & Moderate & Reduced & Developed & Medium \\
\hline Z. gobiensis (Z. lufengensis) & Mixed & Small & Visible & Strong & Rather high & Well developed & Well developed & Large \\
\hline Z. metachinjiensis & Mixed? & Small & & & & Well developed & Well developed & Large and long \\
\hline Maтmut borsoni (Z. shansiensis) & Gracile & Rather small & Visible & Visible & Rather high & Reduced & Well developed & Large to very large \\
\hline M. borsoni & Gracile & Strong & Strong & Visible & High & Well developed & Well developed & Large to very large \\
\hline Tha Chang specimens & Mixed? & Small & Visible & Visible & Moderate & Reduced & Well developed & Medium \\
\hline
\end{tabular}

Table 3. The upper third molars (M3) morphology of the Old Word zygodont proboscideans.

\begin{tabular}{|c|c|c|c|c|c|c|c|}
\hline \multirow[b]{2}{*}{ Taxa } & \multicolumn{7}{|c|}{ Dental morphology } \\
\hline & $\begin{array}{l}\text { Dental } \\
\text { morphotypes }\end{array}$ & $\begin{array}{l}\text { Pretrite } \\
\text { adaxial conelets }\end{array}$ & Zygodont crests & Crescentoids & Cingula & Forth loph & Molar sizes and shapes \\
\hline Losodokodon losodokius & Gracile & Small or absent & Visible & Only anterior of first loph & Well developed & Undeveloped & Very small, narrow \\
\hline Eozygodon morotoensis & Gracile & Small or absent & Visible & 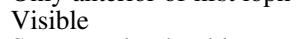 & Well developed in upper molar & Undeveloped & Small \\
\hline Zygolophodon aegyptensis & Robust & Rather strong & Visible & Strong and rather blunt & Well developed & Developed & Small, long and narrow \\
\hline Z. turicensis & Gracile & Strong & Strong & Strong & Well developed & Developed & Medium \\
\hline Z. proavus & Robust & Strong & Visible & Visible & Well developed & Developed & Small to medium \\
\hline Z. gromovae & Gracile? & Small & Absent? & $?$ & $?$ & Less Developed & Large \\
\hline Z. gobiensis (Miomastodon tongxinensis) & Robust & Small & Visible & Visible & Reduced & Developed & Medium \\
\hline Z. gobiensis (Z. (Turicius) nemongnensis) & Gracile & Strong & $\begin{array}{l}\text { Strong in } \\
\text { anterior lophids }\end{array}$ & Visible & Well developed & Well developed & Large and long \\
\hline Z. gobiensis (Z. lufengensis) & Mixed & Small & Visible & Strong & Well developed & Well developed & Large \\
\hline Z. gobiensis (Z. jiningensis) & Robust & - & Strong & Strong & Well developed & Developed & Medium \\
\hline Z. chinjiensis & Robust & Small & Strong & Strong & Well developed & Well developed & Large \\
\hline Z. metachinjiensis & Mixed & Rather small & Visible & Strong & Well developed & Well developed & Large and long \\
\hline $\begin{array}{l}\text { Mammut borsoni } \\
\quad \text { (?Pliomastodon cf. matthewi) }\end{array}$ & & Strong & Visible & Visible & Reduced & Well developed & Large to very large \\
\hline M. borsoni & Gracile & Strong & Strong & Visible & Well developed & Well developed & Large to very large \\
\hline Tha Chang specimens & Mixed? & Small & Visible & Visible & Reduced & Well developed & Medium \\
\hline
\end{tabular}



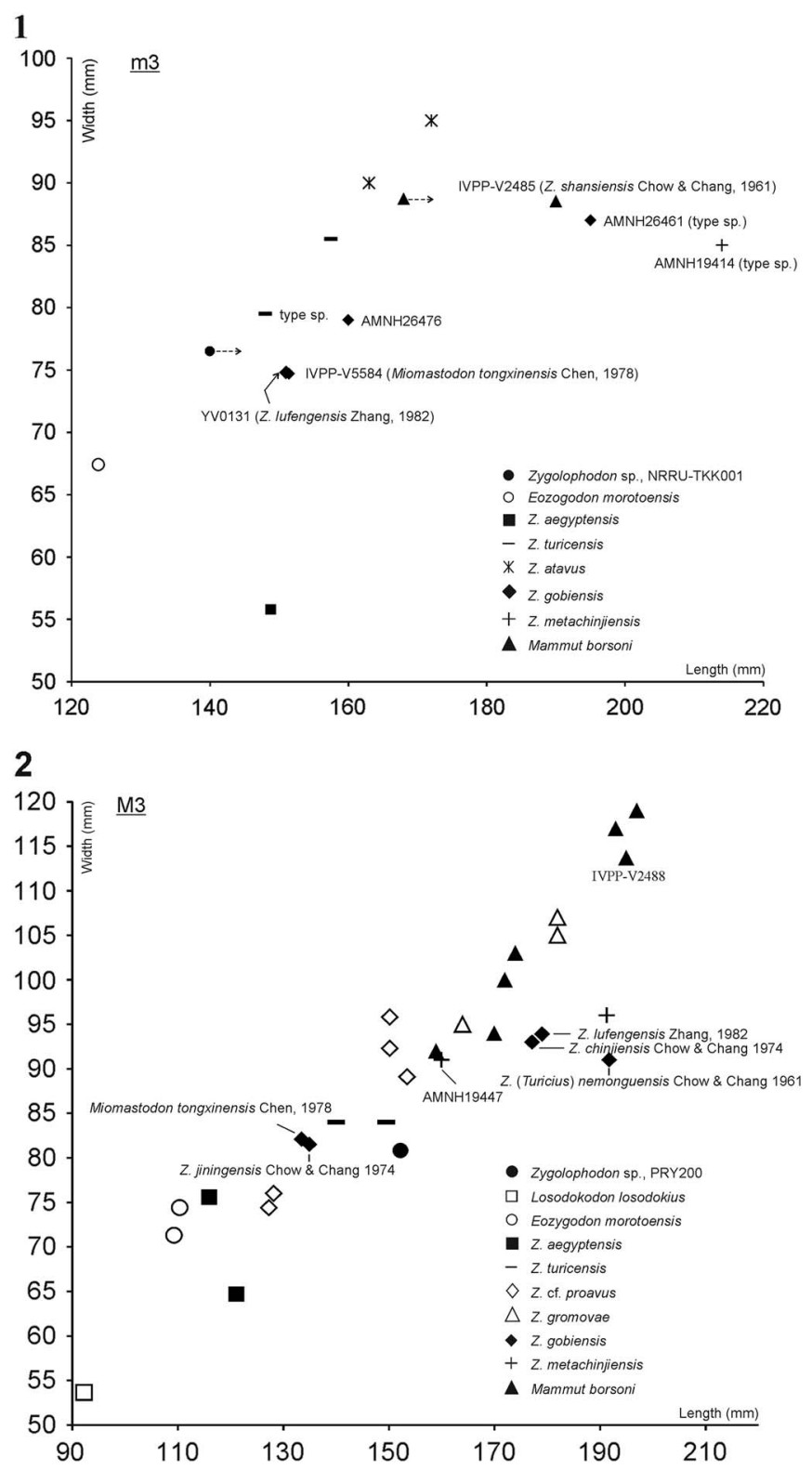

Figure 5. Scatterplot of third molar proportions for various zygodont proboscideans, including Zygolophodon sp. from Tha Chang sand pit no. 10: (1) lower molar, (2) upper molar.

The furrow-like posttrite conelets of the fourth loph(id)s of both Tha Chang specimens resemble the equivalent structures in the middle Miocene European zygolophodont Zygolophodon turicensis Schinz, 1824. The Tha Chang specimens are only slightly narrower than the equivalent molars of $Z$. turicensis but slightly longer in upper molar and slightly shorter in lower molar (in the lower molar case, the length is probably a bit longer than it estimated) (Table 1; Fig. 5.1, 5.2). However, the zygodont crests and cingula of the Tha Chang specimens are reduced, whereas very strong cingula are present in Z. turicensis. In addition, a welldeveloped lingual cingulum is also present in the upper third molar of Z. turicensis from the middle Miocene of Jebel Cherichera, Tunisia (Tassy, 1985, pp. 509-510, fig. 213; Pickford, 2007, p. 30, fig. 2A) and the upper second molars from the Grildain, Ngorora Formation, Member A, Tugen Hills, Kenya
(Pickford, 2007, p. 31, fig. 3). Moreover, the crescentoids of Tha Chang specimens are blunter than those of Z. turicensis (see Tobien, 1975, p. 196, fig. 1; Tassy, 1977, fig. 3, p. 659; Tables 2, 3).

A closer inspection of the molars of the zygodont proboscidean "Mastodon" atavus Borissiak, 1936, from the lower Miocene Djilancik beds of Kazakhstan, will be needed in order to determine whether this specimen is assignable to Z. gobiensis, $Z$. turicensis, or neither. However, the symphysis is longer, and the incisors more strongly developed, than in Z. gobiensis (Tassy, 1985, fig. 201). These differences seem consistent with the somewhat earlier age (Shanwangian/Orleanian) of the Djilancik site. The shortening of the symphysis and incisors seen in Z. gobiensis represents an evolutionary step towards Mammut, in which the symphysis and incisors are reduced (Tobien et al., 1988). The $\mathrm{m} 3$ of $Z$. atavus is larger and much wider than the Tha Chang m3 (Tables 1, 2; Fig. 5.1).

Previously described Chinese zygolophodonts show varying degrees of similarity to the Tha Chang specimens. The type specimen of Zygolophodon gobiensis Osborn and Granger, 1932 (AMNH 26461) is a hemimandible with a complete $\mathrm{m} 2$ and $\mathrm{m} 3$ from the Tunggur locality, Nei Mongol. The m3 of this specimen resembles the Tha Chang $m 3$ NRRU-TKK001 in having small conelets on both pretrite and posttrite sides, a thick talonid on the pretrite, lophids with a low degree of obliquity, weakly developed zygodont crests, a reduced lateral cingulum, and valleys that lack cementum. The $\mathrm{m} 3$ of the type specimen of Z. gobiensis is larger than the Tha Chang specimen; however, the specimen AMNH 26467 is nearly equal in size to Tha Chang m3. In addition, molar has a narrower crown and the main cone and conelets of the fourth lophid are blunter in Z. gobiensis (Tables 1, 2; Fig. 5.1).

Zygolophodon gromovae Dubrovo, 1970 is represented by an upper M2 and M3 (PIN. no. 2002-5, 2002-6 respectively), from the middle Miocene in age of the Tunggur locality, Nei Mongol. In these specimens, small pretrite conelets are present. Upper M3 has three conelets on the posttrite side. The fourth loph is crest-like rather than conule-like (Tobien et al., 1988). In these characters, the M3 of $Z$. gromovae resembles the Tha Chang M3, PRY200. However, the Tha Chang M3 is smaller than the M3 of Z. gromovae and has a better-developed fourth loph (Tobien et al., 1988) (Tables 1, 3; Fig. 5.2). However, the type specimen of Z. gromovae is so badly damaged that its M3 is difficult to compare to the Tha Chang M3 in other respects.

The only representative of Zygolophodon nemonguensis Chow and Chang, 1961, an M3 (IVPP-V2487) from Nei Mongol, has four lophs. The fourth loph is as well developed as that of the Tha Chang M3, PRY200. However, the fourth loph is equal in width to the third loph in IVPP-V2487, but clearly narrower than the third loph in PRY200. The talon of IVPPV2487 is stronger than that of the Tha Chang M3. Nevertheless, the zygodont crest of the first and second posttrite half lophs, the lingual beaded antero-external cingula, and the crescentoids are more prominent in IVPP-V2487 than in PRY200. The pretrite main cone of the fourth loph of PRY200 is larger and more transversely elongate than in IVPP-V2487, and the posttrite half lophs are divided into more conelets. Furthermore, PRY200 is smaller than IVPP-V2487 (Tables 1, 3; Fig. 5.2).

The Zygolophodon jiningensis Chow and Chang, 1974 is an unnumbered M3 from Jining, Nei Mongol. This tooth is unworn, 
but the summits of the three most anterior lophs are so badly broken that cusps cannot be distinguished. This specimen has four lophs and a nodular talon. The posttrites are bicuspid, with small adaxial conelets. In these features, the Jining specimen resembles the Tha Chang M3, PRY200. In particular, the bicuspid nature of the posttrite and the presence of small adaxial conelets can be clearly recognized in the fourth loph of PRY200. However, the fourth loph of PRY200 is better developed than that of the Jining specimen. In addition, the pretrite of the fourth loph of the Jining specimen has two subequal larger mammillae separated by two smaller squeezed ones (see Tobien et al., 1988, p. 151, fig. 42), while the main cone of the Tha Chang specimen is large and transversely elongate with small one adaxial conelets presented (Figs. 2, 4.1). The zygodont crests of the Jining specimen are better developed than in the Tha Chang M3, and the molar is shorter (Tables 1, 3; Fig. 5.2).

Miomastodon tongxinensis Chen, 1978 is represented by an $\mathrm{m} 3$ (IVPP-V5584) and an M3 (IVPP-V5585), from Gujiazhuangzi, Tongxin, Ningxia. The anterior loph of the upper third molar is strongly worn. The third loph has a small adaxial conelet and a strong anterior conule, but no posterior conule is present. The first and third posttrite half lophs have oblique, oppositely oriented long axes, while the second one is normal to the tooth midline. An antero-external cingulum is present. The pretrite side of the fourth loph has an abaxial main cone and a smaller adaxial conelet. In the above characters, the Tongxin M3 resembles the Tha Chang M3, PRY200. However, the Tongxin M3 differs from the Tha Chang M3 in that the posttrite half lophs are bicuspid, zygodont crests are present only in the first and second lophs, and the fourth loph is the narrowest one. The lower third molar is similar to the Tha Chang m3 NRRU-TKK001 in that the third and fourth lophids bear small adaxial conelets, and the upper and lower molars from Tongxin are similar in size to their counterparts from Tha Chang (Tables 1-3; Fig. 5.1, 5.2). Nevertheless, the pretrite and posttrite of the fourth loph(id)s are bicuspid in both Tongxin molars, whereas the posttrite fourth loph is tricuspid in the Tha Chang specimens.

Zygolophodon chinjiensis was named by Osborn (1929) as Serridentinus chinjiensis. The type specimen (AMNH 19447), a right upper third molar (Osborn, 1929, p. 4, fig. 5), bears four ridges and a posterior cingulum. The anterior lophs are each divided into many conelets. We cannot determine whether this character is present in the Tha Chang M3 because of deep wear. However, the fourth loph has a tricuspid posttrite side, and a bicuspid pretrite side. The adaxial conelets are smaller than the main cone, as in the Tha Chang M3. The zygodont crests, crescentoids and lateral cingula of Z. chinjiensis are much stronger than those of the Tha Chang M3. The type specimen of $Z$. chinjiensis is much wider and a bit longer than the Tha Chang M3 (Table 1; Fig. 5.2).

Z. chinjiensis from China was described by Chow and Chang (1978), based on two specimens of M3 (IVPP-V4688.1 and IVPP-V4688.2) from the upper Miocene of Xiaolongtan coal mine, Kaiyuan, Yunnan. These Chinese specimens each bear four lophs with posteriorcingulum and have two conelets on the pretrite side. The third and fourth posttrites are similar to the Tha Chang M3 in being tricuspid, but the main cone of the fourth loph pretrite is less transversely elongated than in the Tha Chang M3. The crescentoids are stronger and the size is larger than in the Tha Chang M3 (Tables 1, 3; Fig. 5.2).
Zygolophodon lufengensis from the upper Miocene (Biasatti et al., 2012) of Shihuiba, Lufeng, Yunnan, was described by Zhang (1982). The holotype, left lower $\mathrm{m} 3$ (Zhang, 1982, pl. 1, fig. 1), bears four lophids with small a posterior cingulum, and the antero-external and pretrite cingula are quite strong. Zygodont crests are visible on the first and second lophids. The conelets on both the pretrite and posttrite half lophids are small. Hence, this specimen can be referred to Zygolophodon gobiensis, (i.e., Tobien et al., 1988) and is similar to the Tha Chang specimens. In addition, the Lufeng $\mathrm{m} 3$ is similar in molar size to Miomastodon tongxinensis and the Tha Chang specimen, but the M3 of Lufeng specimen is larger than both Tongxin and Tha Chang specimens. The m3 of $Z$. lufengensis shows an advanced character state not seen in $M$. tongxinensis and Z. gobiensis, in that the transverse lophids are rather oblique; however, it is also present in the Tha Chang m3 (Tables 1-3; Fig. 5.1, 5.2).

However, Tobien et al. (1988) synonymized many Chinese zygodont proboscideans with Zygolophodon gobiensis, including Zygolophodon gromovae Dubrovo, 1974, Z. (Turicius) nemonguensis Chow and Chang, 1961, Z. nemonguensis Yan, 1979 (M3, IVPP2487), Z. jiningensis Chow and Chang, 1974 (M3, IVPP-5156), Z. chinjiensis Chow and Chang, 1978, Miomastodon tongxiensis Chen, 1978, fragments of M1, IVPP-4685.7 and 4685.8, of Gomphotherium xiaolongtanensis Chow and Chang, 1978, from the upper Miocene of Xiaolongtan coal mine, Kaiyuan, Yunnan.

In addition, Tobien et al. (1988) transferred some species of Zygolophodon to Maтmut borsoni, including an upper D4 (IVPP-V4685) of Zygolophodon sp. from the lower or middle Pliocene of Anle, Huoxian, Shanxi; M3 and m3 (IVPP-VM867 and IVPP-V2485) of Z. shansiensis Chow and Chang, 1961 and M3 (IVPP-V2488) of Zygolophodon sp. (Chow and Chang, 1961) from the upper Pliocene or lower Pleistocene of the Yushe Basin, Shanxi; M2 (IVPP-V4689) of Zygolophodon sp. (Chow et al., 1978) from the Pliocene of Zhaotong, Yunnan. All of the above taxa and specimens are larger in terms of molar size than the Tha Chang specimens, as well as having stronger zygodont crests and lophids that are more obliquely aligned to the long axes of the teeth (Tables 1-3; Fig. 5.1, 5.2).

Zygolophodon metachinjiensis Osborn, 1929 is represented by a right hemimandible with $\mathrm{m} 2$ and $\mathrm{m} 3$ (AMNH 19414) from the middle Miocene of lower Chinji Formation, Chinji, Pakistan. The $\mathrm{m} 3$ has four lophids, and a low posterior cingulum consisting of many accessories this cingulum. Molar is subhypsodont (75 $\mathrm{mm}$ height) and has no cement, and the summits of the lophids each consist of four to five conelets. Tobien (1972) allocated the holotype, lower $\mathrm{m} 2$ and $\mathrm{m} 3$, of Z. metachinjiensis to Gomphotherium by used the character of subhypsodonty and relatively large size of $\mathrm{m} 3$ that were mentioned by Osborn (1936, p.456). However, there are a few details in this holotype. In 1983, Tassy synonymized the upper $\mathrm{M} 3$ of $Z$. chinjiensis and lower $\mathrm{m} 2$ and $\mathrm{m} 3$ of $Z$. metachinjiensis (Osborn, 1929) to Z. metachinjiensis. In this case, after considering the figures of Osborn (1929, figs. 4, 5, 5A and A1) and new material of Tassy (1983a, pl. 2, fig. 2), Tobien et al. (1988) suggested the relations are narrow in their proportions, like the lower and upper second and third molars of Z. gobiensis. The pretrite conelets are rather small in Z. metachinjiensis, 
suggesting this taxon may be closer to Z. gobiensis than to Z. turicensis. If Tobien et al. (1988) are right; the oldest name for Z. gobiensis should be Z. metachinjiensis Osborn, 1929. All Zygolophodon species that were synonymized by Tobien et al. (1988) should also be changed. In the Tha Chang m3 NRRUTKK-001, the transverse lophids are so severely worn that the morphology of the pretrite conelets is generally unclear, except the fourth lophid. In the fourth lophid; however, very small conelets are clearly present on both the pretrite and posttrite sides. The third molars of $Z$. metachinjiensis are much larger, particularly with regard to the length of both the upper and lower molars, than their counterparts from Tha Chang (Tables 1-3; Fig. 5.1, 5.2).

\section{Discussion}

In the course of the "proboscidean datum event" (Madden and van Couvering, 1976), which actually comprised multiple proboscidean dispersals from Africa to Asia and Europe, mammutids initially immigrated, in the end of early Miocene, into Europe, and thereafter into Asia and South Asia (Sanders et al., 2010). In Europe, Tassy (1989) identified Zygolophodon turicensis in MN3b sediments in France. In Eurasia and Asia, the records of these taxa in Pakistan, Kazakhstan, and China occur in sediments that date to, or are slightly younger than, MN4 (Tassy, 1996b; Lucas and Bendukidze, 1997). However, material from the Loh Formation in Central Mongolia appears to be late early to early middle Miocene in age, which would make the specimens in question, slightly younger than the first gomphothere and mammutid immigrants (Göhlich, 2007). However, Mein (1990) thinks that Zygolophodon arrived at Europe coincident with Gomphotherium during MN4. If the Loh Formation indicates late early to early middle Miocene in age and considering the opinion of Mein (1990), the initially migration of mammutids is still unresolved.

The family Mammutidae is characterized by a zygodont pattern (yoke-like transverse crests) of the intermediate and third molars. The oldest, most primitive mammutid is Losodokodon losodokius, from Kenya dated to the late Oligocene (Rasmussen and Gutierrez, 2009). In Eurasia the Mammutidae is only represented by two genera, Zygolophodon and its descendant Maтmut (Konidaris and Koufos, 2009). The oldest Zygolophodon, Z. aegyptensis, is from the lower Miocene of Wadi Moghara, Egypt (Sanders and Miller, 2002 in Konidaris and Koufos, 2009). The only European Zygolophodon representative is the abundant $Z$. turicensis, whose long stratigraphic range in Europe extends from the middle to the upper Miocene (Konidaris and Koufos, 2009). The "Zygolophodon turicensis group" includes four Eurasian species: the type species Z. turicensis Schinz, 1824 from Europe, Z. atavus from Kazakhstan, Z. metachinjiensis from Pakistan and Z. gobiensis from Mongolia and China (Tassy, 1996).

Zygolophodon has not previously been reported from Southeast Asia. The known Zygolophodon specimens closest to the region are from Lufeng, Yunnan, South China, and were identified as Z. lufengensis Zhang, 1982 and Z. chinjiensis (Chow et al., 1978; Zhang, 1982). The new specimens from the Tha Chang sand pits are the first record in Southeast Asia. $Z$. chinjiensis and Z. lufengensis from Yunnan were assigned to
Z. gobiensis by Tobien et al. (1988) on the basis of dental morphology.

Tassy (1985) and Tobien (1996) noted two dental morphotypes within Mammutidae, robust and gracile, however, the dental morphology in this family is indeed high variable (Tables 2,3). The zygodont specimens from the Tha Chang sand pits are close in size to the equivalent teeth of Zygolophodon gobiensis (Miomastodon tongxinensis Chen, 1978, IVPPV5584; Z. gobiensis, AMNH 26467, Tobien et al., 1988) (both lower and upper molars), Z. lufengensis (lower molar) and Z. turicensis (both lower and upper molars), but they are smaller than the holotype of Z. gobiensis, Z. metachijiensis, and Mammut borsoni (Fig. 5.1, 5.2). Tha Chang specimens have small adaxial conelets on both the pretrite and posttrite sides, a feature seen in Zygolophodon specimens from both China and Pakistan. As mentioned above, Tobien et al. (1988) synonymized many species of Zygolophodon with Z. gobiensis, implying high variation in the dental morphology of this species. In addition, they suggested that $Z$. gobiensis was more closely related to Pakistan, Z. metachinjiensis, which share the small pretrite conelets seen in Z. gobiensis, than to Z. turicensis. Nevertheless, the essential diagnostic characters of $Z$. gobiensis are the small anterior pretrite conelets on the upper and lower second and third molars, the fact that the lophids are only slightly oblique. Tha Chang specimens share some of these characters, but lack others.

Although the Tha Chang specimens are deeply worn, it is still evident that their crescentoids are less inflated than in the type specimen of Z. gobiensis, Miomastodon tongxinensis, and $Z$. jiningensis but similar in their degree of inflation to late Miocene Z. lufengensis and Z. chinjiensis. However, the lophids are less oblique and the zygodont crests less well developed than in Z. lufengensis and Z. chinjiensis, as in the type specimen and Miomastodon tongxinensis. The strongly oblique loph(id)s and zygodont crests are more remarkable in the derived zygodont proboscideans such as Mammut (Osborn, 1936; Tobien et al., 1988). The broken specimen of $Z$. gromovae has a loph-like rather than conule-like fourth loph, a point of resemblance to the Tha Chang specimen. In contrast, the fourth loph of the upper M3 of Tha Chang specimen is better developed than in Z. gromovae. South Chinese species have small and strongly divided posttrite adaxial conelets, making them more similar to species from the Pakistan (Z. metachinjiensis) than those from North China (Z. gobiensis, Miomastodon tongxinensis, $Z$. nemonguensis, and $Z$. jiningensis). The Tha Chang specimens share specific features with the zygodonts from the Pakistan and Yunnan such as small adaxial conelets, however, they are deeply worn and broken in the anterior loph(id)s and so it is difficult to establish their precise affinities though it is reasonable to designate them as Zygolophodon sp.

The faunal assemblage in the Tha Chang sand pits no. 1 to 9 includes proboscideans, anthracotheres, pigs, rhinos, bovids, giraffids, horses, apes, crocodiles, and tortoises (Nakaya et al., 2002; Chimanee et al., 2004) (Fig. 1), and indicates a middle Miocene to early Pleistocene age. The middle Miocene mammalian fauna consists of amebelodontine gomphotheres (Protanancus), Gomphotherium, and Prodeinotherium. The late Miocene to early Pliocene fauna includes a new orangutan species Khoratpithecus piriyai Chimanee et al., 2004, a new 
anthracothere species Merycopotamus thachangensis Hanta et al., 2008, a new rhino species Aceratherium porpani Deng, Hanta, and Jintasakul, 2013 (from the same sand pit that yielded the Zygolophodon specimens, Tha Chang sand pit no. 10), horse Hipparion, proboscidean Stegolophodon and a primitive species of Stegodon. The early Pleistocene fauna includes an advanced species of Stegodon (Nakaya et al., 2002, Thasod, 2012). Furthermore, Thasod and Ratanasthien (2005) reported a new species of Sinomastodon more derived than Sinomastodon intermedius from the Pliocene of China. Sinomastodon materials have also been reported from Java (Saegusa, 1995 in van den Bergh, 1999). These specimens were referred to S. bumiajuensis, but their skull and dental features resemble those of Chinese sinomastodonts. In addition, the molars of S. bumiajuensis are more derived than those of Pliocene sinomastodonts from Japan and North China, but very similar to Sinomastodon yangziensis remains from early Pleistocene cave faunas in South China (van den Bergh, 1999).

Although the Zygolophodon specimens from the Tha Chang sand pits were discovered by sand pit workers and their stratigraphic positions are uncertain, their many dental features are similar to the Yunnan species such as in molar size, four lophids with small a posterior cingulum, strong antero-external and pretrite cingula, zygodont crests on the first and second lophids, and small conelets on both the pretrite and posttrite half lophids. In addition, the geographical localities are nearby each other. Furthermore, the teeth of zygodont proboscideans from South China and Pakistan are more gracile or mixed between gracile and robust forms than those of northern Chinese species, which are more robust. The Yunnan specimens have been dated to the late Miocene (Biasatti et al., 2012), and those from Pakistan occur in the lower Chinji Formation (about 14-13 Ma) (Osborn, 1929; Chavasseau et al., 2009). The North China species have been dated to the middle Miocene (Tobien et al., 1988), and might be older than the species from Pakistan. Because of similarity to the Yunnan species regarding both dental morphology and geographical locality, thus, the Tha Chang specimens might be late Miocene in age. However, the size and morphological variation of such teeth make stratigraphic conclusions very tentative.

Among the previously described middle to late Miocene proboscideans from northern Thailand are in Mae Moh coal mine (13.3 and 13.1 Ma), Lam Pang Province include Stegolophodon praelatiden and Gomphotherium cf. browni

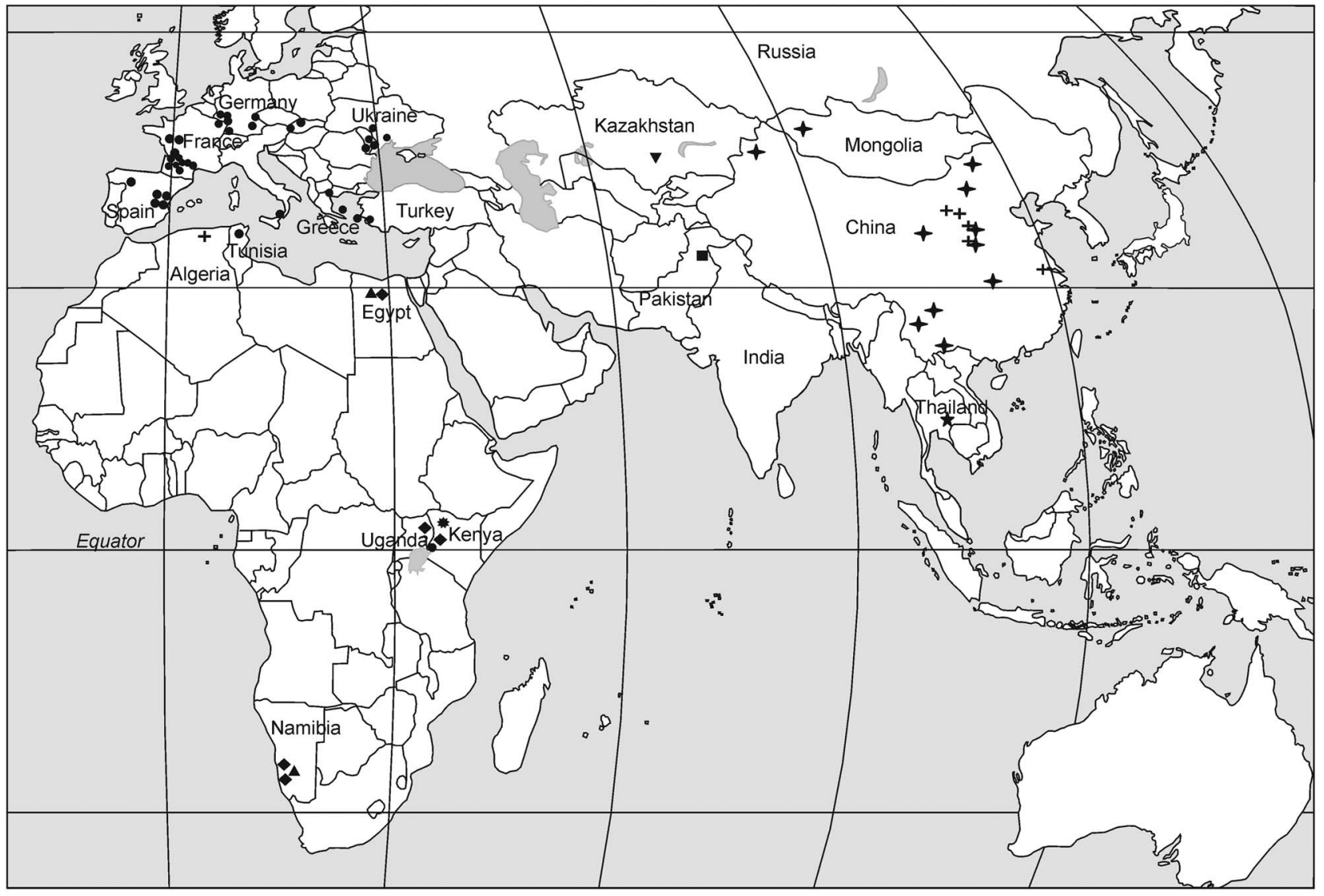

* Losodokodon losodokius, late Oligocene, Kenya

- Eozygodon morotoensis, early-early middle Miocene, Uganda, Kenya, Namibia and Egypt

Aygolophodon aegyptensis, late early-early middle Miocene, Egypt and Namibia

- Zygolophodon turicensis, middle-late Miocene, Kenya, Tunisia and Europe (widespread) ? Zygolophodon?,
- Zygolophodon metachinjiensis, middle-late Miocene, Pakistan

+ Zygolophodon gobiensis, middle-late Miocene, China and Mongolia

v Zygolophodon atavus, early middle Miocene, Kazakhstan

+ Mammut borsoni, late middle Miocene-Pleistocene, China

$\star$ Zygolophodon sp, late middle-late Miocene?, Thailand

Figure 6. Distribution of zygodont proboscideans in the Old World that include the new specimens from Thailand. The oldest zygodont proboscideans have presented in the late Oligocene of Africa and they migrated to Europe and Asia in Miocene (modified data from Tobien et al., 1988; Guan, 1996 in Shoshani and Tassy, 1996; Sanders and Miller, 2002; Pickford, 2007; NOW, 2007; Konidaris and Koufos, 2009; Rasmussen and Gutierrez, 2009). 
(Chavasseau et al., 2009). Then, the Chiang Muan coal mine (12.4-12.2 Ma), Prayao Province, has produced Tetralophodon cf. xiaolongtanensis (Thasod, 2007; Chavasseau et al., 2009). The recognition of G. cf. browni in northern Thailand implies a degree of biogeographic affinity with Pakistan, whereas the presence of Tetralophodon cf. xiaolongtanensis in Chiang Muan is a clear link with the fauna of South China. The most widespread taxa in the middle Miocene of Pakistan are the mammutid Zygolophodon metachinjiensis, the amebelodont Protanancus chinjiensis, the choerolophodont Choerolophodon corrugatus and the gomphothere Gomphotherium browni (Tassy, 1983a, 1983b, fig. 7). The first three taxa have apparently not been recorded from the middle Miocene of Thailand, which points to obvious faunal dissimilarities between Thailand and Pakistan (Chavasseau et al., 2009). The middle Miocene localities of North China have yielded a very different fauna dominated by Zygolophodon, the amebelodont Platybelodon, and supposedly endemic Gomphotherium species (Tobien et al., 1986; Tobien et al., 1988, fig. 7). Thus, the new Zygolophodon specimens in Tha Chang sand pit might indicate a dispersal link between South and East Asian middle and late Miocene proboscideans.

The late Miocene paleoenvironmental record from the Tha Chang sand pits indicates a transition from woodlanddominated to grassland-dominated landscapes (Sepulchre et al., 2010). These results can be correlated to a long-term climatic change that occurred between 8.5 and $6 \mathrm{Ma}$, leading to a major environmental change with $\mathrm{C} 4$ savannas replacing $\mathrm{C} 3$ forests and woodlands (Cerling et al., 1994; Sepulchre et al., 2010). However, the late late Miocene new rhino species, Aceratherium porpani, from the same sand pit as the Zygolophodon materials, is consistent in its chronological implications with the faunal sample from Tha Chang sand pit no. 8, which includes such taxa as Khoratpithecus piriyai and Merycopotamus thachangensis (Chaimanee et al., 2004, 2006; Hanta et al., 2005, 2008; Deng et al., 2013). The occipital surface of the Tha Chang rhino is slightly inclined posteriorly or nearly vertical and the cheek teeth are subhypsodont (Deng et al., 2013). Both features indicate a woodland habitat (Zeuner, 1934).

The zygodont proboscidean discovered in Thailand has significant implications for understanding the dispersal of Zygolophodon. The oldest zygodont proboscidean in Africa, Losodokodon losodokius, is dated to late Oligocene (Rasmussen and Gutierrez, 2009). The oldest Zygolophodon in Europe is in the late early Miocene, either MN3b or MN4 (approximately $17 \mathrm{Ma}$ ) (Drake in Tassy, 1990) while the Zygolophodon materials from Pakistan are in the lower Chinji Formation (approximately 14-13 Ma) (Osborn, 1929; Chavasseau et al., 2009). The North Chinese species are from the middle Miocene (Tobien et al., 1988) and might be older than the species from Pakistan. Finally, the South Chinese species are from the upper Miocene (Biasatti et al., 2012) (Fig. 6). Zygolophodon appears to have dispersed from Africa to Europe in the early Miocene, and become widespread in Asia (especially at middle and high latitudes) in the middle Miocene. Zygolophodon then shifted to low latitude areas such as Thailand in the late Miocene (Fig. 6).

\section{Conclusion}

The zygodont proboscidean teeth from the Tha Chang sand pits (no. 10) show the zygodont pattern. The adaxial conelets are small, more closely resembling Chinese specimens of Zygolophodon gobiensis and Pakistan species Z. metachinjiensis than the holotype species $Z$. turicensis. Despite deep wear, it is evident that the central conules are less inflated than those of the type specimen of $Z$. gobiensis and Miomastodon tongxinensis, but similar to $Z$. lufengensis and Z. chinjiensis from the upper Miocene of South China. However, the Tha Chang specimens are badly worn and the $\mathrm{m} 3$ is broken anteriorly, making it only to designate these specimens as Zygolophodon sp. This Zygolophodon is the first zygodont proboscidean recorded in Southeast Asia and is likely late Miocene in age.

\section{Acknowledgments}

This paper was completed with the help of several people. We would especially like to thank P. Vachajitpan for allowing us to study his collection. We wish to thank to people of the Institute of Vertebrate Paleontology and Paleoanthropology including T. Haowen, who gave us generous suggestions about the proboscideans morphology; C. Sullivan, who advised us about English; and C. Jin, who generously provided us with a comfortable workspace as we studied the specimens in the institute's collections room., We would like to thank to the staffs of the Research Institute of Petrified Wood and Mineral Resources and Nakhon Ratchasima Rajabhat University, especially W. Songtham, W. Rugmai, N. Boonchai, P.J. Grote, K. Jenjitpaiboon, P. Kachenchat, S. Sodok, S. Ruanjangreed, N. Kullaprutmetha, and P. Pipatwatchara for preparing samples and documents as well as making some valuable suggestions while we were studying samples in Thailand. We thank N. Chanon, who gave us a vehicle for comfortable transportation during our work in Thailand. We are grateful for financial support from the National Natural Science Foundation of China (41430102), the Institute of Vertebrate Paleontology and Paleoanthropology, the University of Chinese Academy of Sciences, and Nakhon Ratchasima Rajabhat University.

\section{References}

Biasatti, D., Wang, Y., Gao, F., Xu, Y., and Flynn, L., 2012, Paleoecologies and paleoclimates of late Cenozoic mammals from Southwest China: Evidence from stable carbon and oxygen isotopes: Journal of Asian Earth Sciences, v. 44 , p. $48-61$.

Bergh, G.D. van den, 1999, The Late Neogene elephantoid-bearing faunas of Indonesia: Scripta Geol, v. 117, 388 p.

Blumenbach, J.F., 1799, Handbuch der Naturgeschichte, Sechste Auflage: Johann Christian Dieterich, Göttingen, (I)-XVI, (1)-708 p., 2 pls.

Borissiak, R.L., 1936, Mastodon atavus n. sp., der primitivste Vertreter der Gruppe M. Angustidens: Trav. Inst. Paleozool. Acad. Sci. USSR, v. 5, p. $171-234$.

Buffetaut, E., Helmcke-Ingavat, R., Jaeger, J-J., Jongkanjanasoontorn, Y., and Suteethorn, V., 1988, Mastodon remains from the Mae Teep Basin (northern Thailand) and their biostratigraphic significance: Comptes Rendus de l'Académie des Sciences de Paris, v. 306, p. 249-254.

Cerling, T.E., Quade, J., and Wang, Y., 1994, Expansion and emergence of C4 plants: Nature, v. 371, p. 112-112.

Cerling, T.E., Harris, J.M., and Leakey, M.G., 1999, Browsing and grazing in elephants: the isotope record of modern and fossil proboscideans: Oecologia, v. 120, p. 364-374. 
Chaimanee, Y., Suteethorn, V., Jintasakul, P., Vidthayanon, C., Maradat, B., and Jaeger, J-J., 2004, A New Uran-Utan Ralative from the Late Miocene of Thailand: Nature, v. 427, p. 439-441.

Chaimanee, Y., Yamee, C., Tian, P., Khaowiset, K., Marandat, B., Tafforeau, P., Nemoz, C., and Jaeger, J-J., 2006, Khoratpithecus piriyai, a Late Miocene Hominoid of Thailand: American Journal of Physical Anthropology, v. 131, p. 311-323.

Chavasseau, O., Chaimanee, Y., Yamee, C., Tian, P., Rugbumrung, M., Marandat, B., and Jaeger, J. J., 2009, New Proboscideans (Mammalia) from the middle Miocene of Thailand: Zoological Journal of the Linnean Society, v. 155 , p. $703-721$.

Chen, G., 1978, Some mastodonts from Miocene of Ningxia: Vertebrata Palasiatica, v. 16, p. 103-112 (in Chinese).

Chow, M., and Zhang, Y., 1961, New mastodont from North China: Vertebrata Palasiatica, v. 3, p. 245-261 (in Chinese).

Chow, M., and Zhang, Y., 1974, Proboscidea of China: Beijing, Science Press.

Chow, M., Zhang, Y., and You, Y., 1978, Notes on some mastodons from Yunnan: Professional Papers of Stratigraphy and Palaeontology, v. 7 , p. 68-74.

Deng, T., Hanta, R., and Jintasakul, P., 2013, A new species of Aceratherium (Rhinocerotidae, Perissodactyla) from the Late Miocene of Nakhon Ratchasima, Northeastern Thailand: Journal of Vertebrate Paleontology, v. 33 , p. $977-985$.

Desmarest, A.G., 1822, Mammalogie ou description des espèces de mammifères: Seconde partie, p. $8+$ spl. 277-530, p. 531-555.

Duangkrayom, J., Thasod, Y., and Jintasakul, P., 2010, First Proboscidean fossil record in the southern Thailand: The proceeding of the 2nd Internationa Conference on Paleontology of Southeast Asia (ICPSEA2010), 1-5 November, Mahasarakham University, Mahasarakham, Thailand (Abstract).

Dubrovo, I.A., 1974, New data on masrodonts of western Mongolia: Moscow, Trudy Sovmestn, Soviet-Mongolian Paleont, v. 1, p. 64-73.

Göhlich, U.B., 2007, Gomphotheres (Proboscidea, Mammalia) from the Early-Middle Miocene of Central Mongolia: Ann. Naturhist. Mus. Wien, v. 108 A, p. 271-289.

Haines, P.W., Howard, K.T., Ali, J., Burrett, C.F., and Bunopas, S., 2004, Flood deposits penecontemporaneous with $\sim 0.8$ Ma tektite fall in NE Thailand: impact-induced environmental effects?: Earth and Planetary Science Letters, v. 225, p. 19-28.

Hanta, R., Ratanasthien, B., Kunimatsu, Y., Saegusa, H., Nakaya, H., Nagaoka, S., and Chintasakul, P., 2008, A New species of Bothriodontinae, Merycopotamus thachangensis (Cetartiodactyla, Anthracotheriidae) from the Late Miocene of Nakhon Ratchasima, Northeastern Thailand: Journal of Vertebrate Paleontology, v. 28, p. 1182-1188.

Hay, O.P., 1922, Further observations on some extinct elephants: Proceedings of the Biological Society of Washington, v. 35, p 97-101.

Howard, K.T., Haines, P.W., Burrett, C.F., Ali, J.R., and Bonopas, S., 2003, Sedimentology of 0.8 million-year old log-bearing flood deposits in northeast Thailand and mechanisms for pre-flood deforestation, in Ratanasthien, B., Rieb, L.S., and Chantraprasert, S., eds., RCPNS 46-8th International Congress on Pacific Neogene Stratigraphy, 3-9 February: Special publication, Chiang Mai, Thailand, p. 49-67.

Koenigswald, G.H.R. von, 1959, A mastodon and other fossil mammals from Thailand: Report of Investigation of Royal Department of Mines, v. 2 p 25-28.

Konidaris, G.E., and Koufos, G.D., 2009, The Late Miocene mammal faunas of the Mytilinii Basin: Samos Island, Greece, New Collection, Beitr. Paläont, v. 31, p. 139-155.

Kunimatsu, Y., Ratanasthien, B., Nakaya, H., Saegusa, H., and Nagaoka, S., 2004, Earliest Miocene Hominoid from Southeast Asia: American Journa of Physical Anthropology, v. 124, p. 99-108.

Lofgren, D.L., and Anand, R.S., 2011, Partial skull of Zygolophodon (Mammalia, Proboscidea) from the Barstow Formation of California: Journal of Vertebrate Paleontology, v. 31, p. 1392-1396.

Lucas, S.G., and Bendukidze, O.G., 1997, Proboscidea (Mammalia) from the Early Miocene of Kazakhstan: N. Jb. Geol. Paläont. Mh., Stuttgart, v. 11, p. 659-673.

Madden, C.T., and van Couvering, J.A., 1976, The Proboscidean Datum Event: Early Micoene migration from Africa: Geological Society of America Abstracts with Programs, p. 992.

Mazo, A.V., 1996, Gomphotheres and mammutids from the Iberian Peninsula, in Shoshani, J., and Tassy, P., eds., The Proboscidea Evolution and Palaeoecology of Elephants and Their Relatives: Oxford University Press, Oxford, p. 136-142.

Mazo, A.V., and van der Made, J., 2012, Iberian mastodonts: Geographic and stratigraphic distribution: Quaternary International, v. 255 , p. 239-256.

McKenna, M.C., and Bell, S.K., 1997, Classification of Mammals above the Species Level: New York, Columbia University Press.
Mein, P., 1990, Updating of MN zones, in Lindsay, E.H., Fahlbusch, V., and Mein, P., eds., European Neogene Mammal Chronology: New York, Plenum, p. 73-90.

Nakaya, H., Saegusa, H., Ratanasthien, B., Kunimatsu, Y., Nagaoka, S., and Suganuma, Y., 2002, Neogene Mammalian Biostratigraphy of Thailand: Journal of Vertebrate Paleontology, v. 22, p. 91A (abstract).

Nakaya, H., Saegusa, H., Ratanasthien, B., Kunimatsu, Y., Nagaoka, S., Chintaskul, P., Suganuma, Y., and Fukuchi, A., 2003, Neogene mammalian biostratigraphy and age of fossil ape from Thailand: Asian Paleoprimatology, v. 3, p 66-67 (abstract).

Now 2007, Database with the Neogene localities and their faunal lists www.helsinki.fi/science/now/database.htm.

Osborn, H.F., 1929, New Eurosiatic and American Proboscideans: New York, Amer. Mus. Novitates, v. 393, p. 1-22.

Osborn, H.F., 1936, Proboscidea: A Monograph of the Discovery, Evolution, Migration and Extinction of the Mastodonts and Elephants of the World: Vol. I. Moeritherioidea, Deinotherioidea, Mastodontoidea, Figures courtesy The American Museum of Natural History: New York, American Museum Press, $802 \mathrm{p}$.

Osborn, H.F., and Granger, W., 1932, Platybelodon grangeri, three growth stages and a new Serridentinus from Mongolia: New York, American Museum Press, v. 537, p. 1-13.

Pickford, M., 2007, New mammutid proboscidean teeth from the middle Miocene of tropical and southern Africa: Palaeontologia Africana, v. 42, p. 29-35.

Pickford, M., and Tassy, P., 1980, A new species of Zygolophodon (Mammalia, Proboscidea) from the Miocene hominoid localities of Meswa Bridge and Moroto (East Africa): Neues Jahrbuch für Geologie und Paläontologie, Monatshefte, v. 4, p. 235-251.

Pickford, M., Nakaya, H., Kunimatsu, Y., Saegusa, H., Fukuchi, A., and Ratanasthien, B., 2004, Age and taxonomic status of the Chiang Muan (Thailand) hominoids: Comptes Rendus Palevol, v. 3, p. 65-75.

Rasmussen, D.T., and Gutiérrez, M., 2009, A mammalian fauna from the late Oligocene of northwestern Kenya: Palaeontographica, Abt. A, v. 288, p. 1-52.

Saegusa, H., 1995, Phylogenetic relationships of Stegodon and Sinomastodon (Proboscidea, Mammalia) of the Mainland of East Asia, in, Int., Symp., Biogeogr., Vertebrates in Indonesian Islands and Adjacent Area and Comparative Anatomy of Early Hominids and other Mammals, Kashiwa, Japan.

Saegusa, H., Ratanasthien, B., and Nakaya, H., 1999, A New Miocene Mammalian Locality, Mae Soi, and the Occurrence of Partial Skeletons of Rhinocerotids and Gomphotheres from Northern Thailand, in Ratanasthien, B., and Rieb, S.,L., eds., Proceedings of the International Symposium Shallow Tethys (ST) 5: Chiang Mai, Thailand, p. 440-449.

Sanders, W.J., 1996, Fossil proboscideans of the Manonga Valley, Tanzania: Journal of Vertebrate Paleontology, v. 16, p. 62A-63A.

Sanders, W.J., and Miller, E.R., 2002, New Proboscideans from the Early Miocene of Wadi Moghara, Egypt: Journal of Vertebrate Paleontology, v. 22 (2), p. $388-404$.

Sanders, W.J., Kappelman, J., and Rasmussen, D.T., 2004, New largebodied mammals from the late Oligocene site of Chilga, Ethiopia: Acta Palaeontologica Polonica, v. 49, p. 365-392.

Sanders, W.J., Gheerbrant, E., Harris, J.M., Saegusa, H., and Delmer, C., 2010 , Proboscidea, in Werdelin, L., and Sanders, W.J., eds., Cenozoic mammals of Africa: Berkeley, Los Angeles, London, University of California Press, p. $161-215$.

Sato, Y., 2002, Preliminary Report on the Occurrence of Fossil Mammals in Nakhon Ratchasima, Northeast Thailand, in Mantajit, N., and Potisat, S., eds., The Proceedings of the Symposium on Geology of Thailand 26-31 August 2002: Bangkok, Thailand, p. 230-232.

Schinz, H.R., 1824, . Naturgeschichte und Abbildungen der Saugethiere: Brodtmanns Lithographische Kunstanstalt, Zurich, vi +417 , Atlas, 177 plts.

Sepulchre, P., Jolly, D., Ducrocq, S., Chaimanee, Y., Jaeger, J.J., and Raillard, A. 2010, Mid-Tertiary paleoenvironments in Thailand: pollen evidence: Climate of the Past, v. 6, p. 461-473.

Shoshani, J., and Tassy, P., (eds.), 1996, The Proboscidea: Evolution and Palaeoecology of Elephants and Their Relatives: Oxford, Oxford University Press, $472 \mathrm{p}$.

Shoshani, J., and Tassy, P., 2005, Advances in proboscidean taxonomy and classification, anatomy and physiology, and ecology \& behavior: Quaternary International, v. 5-20, p. 126-128.

Suganuma, Y., Hamada, T., Tanaka, S., Okada, M., Nakaya, H., Kunimatsu, Y., Saegusa, H., Nagaoka, S., and Ratanasthien, B., 2006, Magnetostratigraphy of the Miocene Chiang Muan Formation, northern Thailand: Implication for revised chronology of the earliest Miocene hominoid in Southeast Asia: Palaeogeography, Palaeoclimatology, Palaeoecology, v. 239 , p. $75-86$

Suteethorn, V., Chaimanee, Y., and Khansupa, S., 1997, Preliminary Report on the Tertiary Vertebrate Fossil of Khorat Basin, Thailand: Annual Meeting and Presentation of Geological Survey Division, p. 111-113 (in Thai). 
Tassy, P., 1977, Découverte de Zygolophodon turicensis (Schinz) (Proboscidea, Mammalia) au lieu-dit Malartic à Simorre, Gers (Vindobonien moyen); implications paléoécologiques et biostratigraphiques: Geobios, v. 10, p. 655-669.

Tassy, P., 1983a, Les Elephantoidea Miocènes du plateau du Potwar, Groupe de Siwalik, Pakistan. Premiere partie: introduction, cadre chronologique et géographie, mammutidés, amébélodontidés: Annales de Paléontologie, v. 69 , p. $99-136$.

Tassy, P., 1983b, Les Elephantoidea Miocènes du plateau du Potwar, Groupe de Siwalik, Pakistan, Deuxième partie: Choerolophodontes et Gomphothères: Annales de Paléontologie, v. 69, p. 235-297.

Tassy, P., 1983c, Les Elephantoidea Miocènes du plateau du Potwar, Groupe de Siwalik, Pakistan, Troisième partie: Stégodontidés, Eléphantoïdes indéterminés, Restes postcraniens, Conclusions: Annales de Paléontologie, v. 69, p. $317-354$.

Tassy, P., 1985, La place des mastodontes miocènes de l'Ancien Monde dans la phylogénie des Proboscidea (Mammalia): hypothèses et conjectures: $\mathrm{PhD}$. Thesis, Université Pierre et Marie Curie.

Tassy, P., 1986, Nouveaux Elephantoidea (Mammalia) dans le Miocène du Kenya: Paris, Cahiers de Paleontologie, Éditions du Centre de la Recherche Scientifique, $135 \mathrm{p}$.

Tassy, P., 1989, The "Proboscidean Datum Event": How many proboscideans and how many events?, in Lindsay E.H., Fahlbusch V., and Mein P., eds., European Neogene Mammal Chronology: New York, Plenum Press, p. $237-252$.

Tassy, P., 1990, Phylogénie et classification des Proboscidea (Mammalia): historique et actualité: Annales de Paléontologie, v. 76, p. 159-224.

Tassy, P., 1996a, Dental homologies and nomenclature in the Proboscidea, in Shoshani, J., and Tassy, P., eds., The Proboscidea Evolution and Palaeoecology of Elephants and Their Relatives: Oxford, Oxford University Press, p. 21-25.

Tassy, P., 1996b, The earliest gomphotheres, in Shoshani, J., and Tassy, P., eds., The Proboscidea. Evolution and palaeoecology of elephants and their relatives: Oxford, Oxford University Press, p. 89-91.

Tassy, P., and Pickford, M., 1983, Un nouveau mastodonte zygolophodonte (Proboscidea, Mammalia) dans le Miocene inferieur d'Afrique orientale systematique et paleoenvironment: Geobios, Lyon, v. 16, p. 53-57.

Tassy, P., Anupandhanant, P., Ginsburg, L., Mein, P., Ratanasthien, B., and Suteethorn, V., 1992, A new Stegolophodon (Proboscidea, Mammalia) from the Early Miocene of Northern Thailand: Geobios, v. 25, p. 511-523.

Thasod, Y., 2007, Miocene Mastodont in Thailand and Paleoenvironment: Ph.D. thesis, The Graduate School, Chiang Mai University, 368 p.
Thasod, Y., and Ratanasthien, B., 2005, New Proboscideans, Sinomastodon (Proboscidea, Mammalia) from Thailand, in Wannakao, L, Srisuk, K., Youngme, W., and Lertsirivorakul, R, eds., The Proceeding of the International Conference on Geology, Geotechnology and Mineral Resources of Indochina (GEOINDO 2005) 28-30 November, p. 594-599.

Thasod, Y., Jintasakul, P., and Ratanasthien, B., 2011, Proboscidean Fossil from the Tha Chang Sand Pits, Nakhon Ratchasima Province, Thailand: J. Sci., Technol., MSU, v. 31, p. 33-44.

Tobien, H., 1973b, The structure of the mastodont molar (Proboscidea, Mammalia), Part 1: The bunodont pattern: Mainzer Geowissenschaftliche Mitteilungen, Mainz, v. 2, p. 115-147.

Tobien, H., 1975, The structure of the mastodont molar (Proboscidea, Mammalia), Part 2: The zygodont and zygobunodont patterns: Mainzer Geowissenschaftliche Mitteilungen, Mainz, v. 4, p. 195-233.

Tobien, H., 1996, Evolution of zygodonts with emphasis on dentition, in Shoshani, J, and Tassy, P., eds., The Proboscidea. Evolution and Palaeoecology of Elephants and Their Relatives: Oxford, Oxford University Press, p. 76-85.

Tobien, H., Chen, G., and Li, Y., 1986, Mastodonts (Proboscidea, Mammalia) from the Late Neogene and Early Pleistocene of the People's Republic of China, Part 1, Historical account: the genera Gomphotherium, Choerolophodon, Synconolophus, Amebelodon, Platybelodon, Sinomastodon: Mainzer geowissenschaftliche Mitteilungen, v. 15, p. 119-181.

Tobien, H., Chen, G., and Li, Y., 1988, Mastodonts (Proboscidea, Mammalia) from the Late Neogene and Early Pleistocene of the People's Republic of China, Part 2, The genera Tetralophodon, Anancus, Stegotetrabelodon, Zygolophodon, Mammut, Stegolophodon: Mainzer geowissenschaftliche Mitteilungen, v. 17, p. 95-220.

Vacek, M., 1877, Ueber Reste von Mastodon aus tertiären Ablagerungen Oesterreichs: Verh. geol. Reichsanst, p. 52-53.

Yan, D., 1979, Einige der fossilen miozanen Saugetiere der Kreis von Fangxian in der Provinz Hupei: Vertebrata Palasiatica, v. 17, p. 191-199 (in Chinese and German).

Zeuner, F.E., 1934, Die Beziehungen zwischen Schädelform und Lebenweise bei den rezenten und fossilen Nashörnern: Berichte der Naturforschenden Gesellschaftzu Freiburg, v. 34, p. 21-79.

Zhang, X., 1982, The fossil of Pliocene Elephantoidea from the basin of Lufeng, Yunnan: Vertebrata PalAsiatica, v. 20, p. 359-367 (in Chinese).

Accepted 2 September 2016 